\title{
PERANAN MUATAN LOKAL MATERI BATIK TULIS LASEM SEBAGAI BENTUK PELESTARIAN BUDAYA LOKAL
}

\section{Muhammad Nur Farid ${ }^{\bowtie}$}

Madrasah Aliyah Al-Asror Gunung Pati, Semarang, Indonesia

\section{Info Artikel}

Sejarah Artikel:

Diterima Desember 2011

Disetujui Januari 2012

Dipublikasikan Maret 2012

\section{Keywords:}

Roles;

Local Content ;

Batik;

Cultural Preservation.

\begin{abstract}
Abstrak
Penelitian ini bertujuan mengkaji bagaimana pelaksanaan muatan lokal batik tulis Lasem pada tingkat sekolah dasar di Kecamatan Lasem sebagai bentuk pelestarian budaya lokal. Hasil penelitian ini menunjukkan pelaksanaan muatan lokal batik tulis Lasem pada kelas empat dan kelas lima. Masing-masing tingkatan mempunyai fokus kemampuan yang berbeda. Fokus kelas empat adalah pengenalan tentang batik, alat dan bahan membatik serta pengenalan ragam hias batik, sedang fokus kelas lima adalahpenjelasan sejarah batik tulis Lasem, tahapan membatik batik tulis Lasem, ragam hias batik tulis Lasem. Praktik pada kelas lima mulai dari ngethel, membuat pola, nglengkreng, nerusi, dan isen-isen. Pelaksanaan muatan lokal batik tulis Lasem kelas enam yaitu tentang sejarah dan ragam hias batik tulis Lasem melanjutkan tahapan dari kelas lima yang belum selesai. Muatan lokal tersebut berhasil menanamkan kepedulian dan kecintaan anak-anak pada batik tulis Lasem.

Abstract

The objective of this study is to examine the implementation of the local content batik Lasem at primary school in Lasem subdistrict as a form of local cultural preservation. The result of this study demonstrates that $t$ local content batik Lasem is implemented in fourth, fifth and sixth grade. Each level has different focus. The focus of the fourth grade is the introduction of batik, batik tools and materials as well as the introduction of decorative batik. The focus of the fifth grade is on the history of Lasem batik, barik stages, decorative Lasem batik. The practice in fifth grade include ngethel, make patterns, nglengkreng, nerusi, and isen-isen. The implementation of the local content batik Lasem at sixth grade is about the history and decorative batik Lasem continuing the unfinished subjects in the fifth grade. Local content successfully instill kids' awarness and love on batik Lasem.
\end{abstract}

(C) 2012 Universitas Negeri Semarang 


\section{PENDAHULUAN}

Menurut Departemen Pendidikan Nasional, muatan lokal merupakan kegiatan kulikuler untuk mengembangkan kompetensi yang disesuaikan dengan ciri khas dan potensi daerah, yang materinya tidak dapat dikelompokkan kedalam mata pelajaran yang ada. Muatan lokal sebagai program pendidikan dimana isi dan media penyampaiannya dikaitkan dengan lingkungan alam, lingkungan sosial, dan lingkungan budaya serta kebutuhan pembangunan daerah yang perlu diajarkan (Musanna 2009).

Muatan lokal ditujukan untuk menjembatani antara kebutuhan keluarga dan masyarakat serta disesuaikan dengan tujuan pendidikan nasional. Muatan lokal juga dapat memberikan wawasan di sekitar peserta didik dan memberikan peluang untuk mengembangkan kemampuan dirinya yang dianggap perlu oleh daerah yang bersangkutan.

Salah satu daerah yang menerapkan mata pelajaran muatan lokal sebagai salah satu upaya dalam pelestarian budaya daerah adalah Kebupaten Rembang. Kabupataen Rembang merupakan salah satu daerah yang menerapkan sebuah kebijakan baru yaitu menerapkan mata pelajaran muatan lokal batik tulis Lasem di sekolah, khususnya di sekolah dasar. Kebijakan ini muncul berawal dari masalah yang terjadi di indutri batik tulis Lasem.

Awalnya karena ada rasa prihatin, kemudian kami (Dinas Pendidikan Kabupaten Rembang) melakukan survey kepada para juragan batik di seluruh kabupaten Rembang. kami menemukan bukti bahwa para pembatik mulai meninggalkan pekerjaan membatik, karena mereka beranggapan bahwa pendapatan membuat batik sekarang ini tidak sesuai untuk kebutuhan sehari-hari. Apalagi para pembatik batik tulis Lasem sebagian besar umurnya diatas 40 tahun. Kemudian Dinas Pendidikan Kabupaten Rembang juga menemukan fakta bahwa para anak dari buruh batik kurang tertarik untuk bekerja sebagai pembatik. (Hasil wawancara dengan Ibu Kusrini, 42 tahun, Dinas Pendidikan Kabupaten Rembang pada tanggal 26 April 2011).

Melihat kondisi seperrti itu, kemudian pemerintah Kabupaten Rembang ada rasa ketakutan akan hilangnya budaya lokal tersebut. Melihat dari sejarah panjang batik tulis Lasem merupakan akulturasi budaya cina dengan budaya jawa. Faktor sejarah inilah yang menjadi identitas budaya lokal kabupaten Rembang yang harus dilestarikan. Ditambah adanya bukti para pembuat batik atau buruh batik mulai meninggalkan pekerjaan tersebut karena pendapatan membatik tidak cukup untuk memenuhi kebutuhan sehari-hari. Dari generasi muda sendiri juga kurang tertarik dengan pekerjaan membatik. Anak muda lebih tertarik pekerjaan lain yang lebih menjanjikan.

Kondisi seperti ini kemudian menjadi perhatian Pemerintah untuk menjadikan budaya batik tulis Lasem sebagai aset budaya daerah. Langkah-langkah yang diambil oleh Pemerintah yaitu menjadikan budaya batik tulis Lasem ini dimasukkan kedalam proses pembelajaran atau disebut sebagai muatan lokal batik tulis Lasem.

Pertimbangan yang diambil dari Dinas Kabupaten Rembang karena dalam muatan lokal itu kita mengedepankan aspek-aspek di daerah setempat, karena kita tahu rembang itu kaya akan budaya yang mana sampai saat ini banyak generasi muda itu tidak mengenal, sehingga untuk memperkenalkan budaya yang ada, maka muatan lokal batik ini perlu kami berikan pada generasi muda mulai dari sekolah dasar (Hasil wawancara dengan Ibu Kusrini, 42 tahun, Dinas Pendidikan Kabupaten Rembang pada tanggal 26 April 2011).

Pertimbangan ini diambil pemerintah untuk melaksanakan muatan lokal, khususnya muatan lokal batik tulis Lasem. 
terdapatnya muatan lokal batik tulis Lasem diharapkan dapat mengenalkan budaya lokal yang ada pada generasi muda khususnya generasi muda Kabupaten Rembang. Muatan Lokal Batik Tulis Lasem diajarkan pada sekolah khususnya sekolah dasar. Tujuan Dinas Pendidikan Kabupaten Rembang menerapkan muatan lokal batik tulis Lasem pada tingkat sekolah dasar yaitu:

Karena dengan memberikan pengenalan sedini mungkin itu harapan kami itu mereka akan mencintai, begitu mereka mencintai maka dia akan berusaha untuk bagaimana agar budaya kita istilahnya di uriuri dan dilestarikan. Untuk belajar membatik itu tidak mungkin kalau tidak menggunakan hati. Harapan kami dengan sedini mungkin kita perkenalkan pada anak-anak di SD khususnya itu nanti kan batik itu tidak hanya menjadi pekerjaan alternatif namun bisa menjadi pilihan utama. Karena selama ini pekerjaan jadi pembatik dan pengusaha batik karena itu mereka tidak memiliki pekerjaan lain yang lebih menjanjikan. Tapi mulai tahun 2009 kemarin adanya pengakuan UNESCO tentang batik sebagai warisan budaya nusantara dan sudah diakui dunia, sekarang banyak bermunculan pengusaha-pengusaha batik di daerah Lasem. dan usaha batik ternyata merupakan usaha yang menjanjikan dari segi ekonomi maupun sosial, dengan peningkatan ekonominya akhirnya kan strata sosialnya juga meningkat. Harapan kami dengan sedini mungkin anakanak diperkenalkan dengan batik, dia nanti menjadi bangga, jadi misalnya mereka jadi pengusaha batik itu tidak karena pilihan kedua namun pilihan pertama (Hasil wawancara dengan Ibu Kusrini, 42 tahun, Dinas Pendidikan Kabupaten Rembang pada tanggal 26 April 2011).

Dengan mengenalkan budaya batik tulis Lasem sejak sedini mungkin, pemerintah memiliki harapan, agar generasi muda masyarakat Rembang, khususnya anak-anak sekolah dasar di Kabupaten Rembang lebih mengenal budaya daerahnya dan peduli dengan budaya tersebut. Kepedulian dalam melestarikan batik tulis Lasem tidak dapat asal-asalan, harus menggunakan hati atau perasaan dalam hati untuk mencintai batik dan melestarikannya. Dimana keberadaan batik tulis Lasem menjadi bagian tak terpisahkan dari kehidupan masyarakat baik secara ekonomi, sosial, maupun budaya.

Setiap sekolah dasar di Kecamatan Lasem melaksanakan muatan lokal batik tulis Lasem memiliki latar belakang yang berbeda-beda. Terdapat poin yang di ambil oleh masing-masing sekolah yaitu faktor letak secara geografis sekolah, kemampuan guru yang dapat membatik, keinginan yang kuat untuk melestarikan budaya batik, dan ditunjuk oleh pemerintah. Sehingga masingmasing sekolah menerapkan muatan lokal batik tulis Lasem memiliki karakter yang berbeda-beda. Pelaksanaan muatan lokal ini dilaksanakan pada tingkat sekolah dasar.

Pertanyaan dalam penelitian ini adalah bagaimana pelaksanaan pembelajaran muatan lokal batik tulis Lasem pada tingkat sekolah dasar di kecamatan Lasem?

\section{METODE PENELITIAN}

Lokasi penelitian ini pada umumnya berada di Kecamatan Lasem. Kecamatan Lasem merupakan daerah yang paling banyak masyarakatnya bekerja sebagai buruh batik. Terhitung ada 6 Desa yang pekerjaan utama masyarakat tersebut sebagai pembatik. Penelitian dilakukan di 5 SD di Lasem.

\section{HASIL DAN PEMBAHASAN}

\section{Tiga alasan mengapa batik Lasem}

Terdapat beberapa alasan dari Sekolah Dasar di Kecamatan Lasem dalam menerapkan muatan lokal batik tulis Lasem. Alasan ini menjadi dasar masing-masing sekolah dasar di kecamatan Lasem ingin menerapkan muatan lokal batik tulis Lasem. 
Alasan dapat dikategorikan menjadi tiga, yaitu :

\section{a) Letak geografis sekolah}

Keberadaan sekeliling sekolah menjadi pertimbangan dari pihak sekolah untuk menerapkan muatran lokal. Sekolah dasar yang mempertimbangkan penerapan muatan lokal batik tulis Lasem dari faktor ini yaitu SD Selopuro 2, SD Karasgede, dan SD Jolotundo 2.

\section{Alasan yang pertama karena di lingkungan SD Selopuro ini banyak yang pekerjaannya pembatik paling tidak anak-anak harus bisa membatik. Dirumah pun anak-anak juga belajar membatik karena sebagain orantua ada yang bekerja sebagai pembatik. (Hasil wawancara dengan Ibu Sri, 55 tahun, guru, pada tanggal 10 April 2011).}

SD Selopuro 2 menerapkan muatan lokal batik tulis Lasem dilatarbelakangi oleh keberadaan sekolah tersebut berada di sekitar masyarakat yang bekerja sebagai pembatik. Sehingga siswa sekolah dasar tersebut paling tidak bisa melakukan praktik membatik batik tulis Lasem. Disamping hal tersebut juga terdapat beberapa anak yang telah bisa melakukan praktik membatik batik tulis Lasem.

SD Karasgede juga dilatarbelakangi oleh keberadaan sekolah tersebut berada di sekitar lingkungan para pembatik. Kepala sekolah SD Karasgede menerangkan: :

Di desa Karas terdapat perusahaan batik serta sebagian besar masyarakat disekitar sekolah SD Karasgede ini adalah pembatik. sehingga saya dapat dengan mudah untu melakukan kerja sama. (Hasil wawancara dengan Ibu Diyarti, 51 tahun, kepala sekolah, pada tanggal 27 Maret 2011).

Keberadaan perusahan batik di desa Karasgede menjadi alasan bagi kepala sekolah dasarKarasgedeuntuk melaksanakan muatan lokal batik tulis Lasem. Apalagi sekitar keberadaan sekolah sebagian besar masyarakatnya bekerja sebagai pembatik. Serta ketika pihak sekolah mau melakukan kerjasama dengan pihak perusahaan batik dapat dengan mudah untuk melakukannya.

Lain lagi alasan dari SD Jolotundo 2, kepala sekolah SD Jolotundo 2 memiliki pandangan lain :

Anak-anak dari SD Jolotundo 2 kan dari anak-anak pinggiran, intinya tidak dari dalam kota. Sehingga untuk melaksanakan muatan lokal komputer itu kok dirasa kurang tepat. (Hasil wawancara dengan Bapak Juwanto, 50 Tahun, kepala sekolah, pada tanggal 10 April 2011)

Keberadaan dari SD Jolotundo 2 yang jauh dari pusat kota kecamatan yang menjadi alasan menerapkan muatan lokal batik tulis Lasem. Kepala sekolah beranggapan bahwa untuk kemampuan anak-anak pinggiran yang jauh dari pusat kota untuk melakukan muatan lokal komputer dirasa kurang tepat. Sehingga kepala sekolah SD tersebut menerapkan muatan lokal batik tulis Lasem.

\section{b) Kemampuan yang dimiliki guru}

Faktor kemampuan yang dimiliki guru yang mengajar di sekolah dasar juga menjadi pertimbangan bagi pihak sekolah untuk menerapkan muatan lokal batik tulis Lasem. Kemampuan ini menjadi acuan bagi kepala sekolah ingin menerapakan muatan lokal batik tulis Lasem. terdapat beberapa sekolah yang mempertimbangkan melaksanakan muatan lokal batik tulis Lasem dari faktor kemampuan guru. Sekolah dasar tersebut yaitu SD Dorokandang, SD Karasgede, SD Jolotundo, dan SD Karangturi.

Di SD Dorokandang 2 memiliki guru yang dapat membuat batik tulis Lasem. Kepala sekolah SD Dorokandang 2 menjelaskan:

Disamping itu juga GTT namanya $\mathrm{Bu}$ Jarwati dia ternyata juga mempuyai bakat membatik apalagi dia masuk di forum PLS (Pendidikan Luar Sekolah) dan dia ditugasi untuk pengembangan 
batik di masyarakat. Sehingga saya kondisikan sebagai guru muatan lokal batik. (Hasil wawancara dengan Ibu Kadarwati, 43 tahun, kepala sekolah, pada tanggal 24 April 2011)

Di SD Dorokandang 2 memiliki guru GTT yang memilii bakat membatik batik tulis Lasem. apalagi guru GTT tersebut masuk dalam forum PLS (Pendidikan Luar Sekolah) dan guru GTT tersebut mendapat tugas untuk mengembangkan batik di masyarakat. Dari faktor inilah yang menjadikan kepala sekolah SD Dorokandang 2 menerapakan muatan lokal batik tulis Lasem.

SD Karasgede juga memiliki guru yang dapat membatik. Kepala sekolah SD Karasgede menjelaskan:

Kebetulan pada tahun 2008 dari jakarta dari IPI datang kewilayah kabupaten Rembang dan mengadakan penataran batik yang dipimpin oleh Bapak Willy yang dilaksanakan di SD Jeruk di kecamatan Pancur. Kebetulan juga SD Karas ikut di dalamnya dan sayapun berkemauan kuat supaya SD saya bisa dijadikan contoh. Dengan itulah saya semakin bersemangat untuk melatih anak-anak membatik. (Hasil wawancara dengan Ibu Diyarti, 51 tahun, kepala sekolah, pada tanggal 27 Maret 2011).

Pada saat ada penataran batik dari IPI kepala sekolah SD Karasgede dilibatkan di dalam acara tersebut. Apalagi kepala sekolah SD tersebut memiliki kemampuan membatik batik tulis Lasem karena berasal dari keluarga pembatik. Latar belakang inilah yang menjadikan kepala sekolah memiliki kemauan yang kuat untuk melaksanakan muatan lokal batik tulis Lasem di SD Karasgede.

SD Jolotundo melaksanakan muatan lokal batik tulis Lasem juga dilatar belakangi dari kemampuan yang dimiliki oleh guru yang mengajar di SD tersebut. Kepala sekolah menjelaskan:

\begin{abstract}
Awalnya SD Jolotundo memiliki guru yang di ikutkan pelatihan membatik oleh kepala sekolah. Namun guru yang ikut pelatihan kemudian pindah di SD lain. Sehingga kepala sekolah menunjuk guru yang masih GTT untuk mengajar muatan lokal batik tulis Lasem, dan ternyata guru GTT tersebut dapat membatik batik tulis Lasem, karena berasal dari keluarga pembatik (Hasil wawancara dengan Bapak Juwanto, 50 Tahun, kepala sekolah, pada tanggal 10 April 2011).
\end{abstract}

SD Jolotundo melaksanakan muatan lokal batik tulis Lasem karena terdapat guru yang ditunjuk untuk mengajar muatan lokal batik tulis Lasem dapat membatik. Guru tersebut merupakan dari keluarga pembatik. Guru GTT tersebut juga pernah diajari oleh orangtuanya untuk membatik. Pengalaman dan kemampuan dapat membuat batik tulis Lasem ini yang menjadi keputusan kepala sekolah untuk melaksanakan muatan lokal batik tulis Lasem.

\section{c) Anjuran dari pemerintah kabupaten Rembang Ada sekolah dimana penerapan} muatan lokal berasal dari ajuran pemerintah.

SD Selopuro merupakan tunjukan dari pemerintah untuk melaksanakan muatan lokal batik tulis Lasem. Pemerintah menganjurkan bagi sekolah dimana keberadaannya dekat dengan batik maka hendaknya menerapkan muatan lokal batik. (Hasil wawancara dengan Ibu Sri, 55 tahun, guru, pada tanggal 10 April 2011).

Harapan dari pemerintah Kabupaten Rembang yaitu setiap sekolah yang keberadaannya dekat dengan para pembatik sebaiknya menerapakn muatan lokal sesuai dengan budaya setempat. Salah satu yang ditunjuk untuk menerapkan muatan lokal batik tulis Lasem adalah sekolah dasar SD Selopuro 2. 
Tabel 1. Standar Kompetensi dan Kompetensi Dasar Pelajaran Muatan Lokal Batik Tulis Lasem kelas V

\begin{tabular}{|c|c|c|c|}
\hline kelas & Semester & Standar Kompetensi & Kompetensi Dasar \\
\hline $\mathrm{V}$ & $\mathrm{I}$ & $\begin{array}{l}\text { 1. Memahami batik } \\
\text { tulis khas Lasem }\end{array}$ & $\begin{array}{l}\text { 1.1. Memahami sejarah batik } \\
\text { tulis Lasem } \\
\text { 1.2. Mengidentifikasi ragam hias } \\
\text { batik Lasem } \\
\text { 1.3. Mengidentifikasi warna } \\
\text { batik tulis Lasem } \\
\text { 2.1.membuat pola dasar ragam } \\
\text { hias batik tulis Lasem }\end{array}$ \\
\hline
\end{tabular}

\begin{tabular}{|c|c|c|}
\hline & $\begin{array}{l}\text { 2. Mengeskpresikan } \\
\text { seni batik }\end{array}$ & \\
\hline V $\quad$ II & $\begin{array}{l}\text { 3. Memahami teknik } \\
\text { membatik }\end{array}$ & $\begin{array}{l}\text { 3.1. Memahami proses dasar- } \\
\text { dasar membatik } \\
\text { 3.2. Melakukan kegiatan } \\
\text { berkaiatan dengan teknik- } \\
\text { teknik dasar membatik. }\end{array}$ \\
\hline
\end{tabular}

Sumber: Sugiarharto, Dkk, (2008-1)buku ajar kelas lima

Tujuan menerapkan muatan lokal batik tulis Lasem

Tujuan penerapan muatan lokal batik tulis Lasem pada tingkat sekolah dasar di kecamatan Lasem tidak memiliki perbedaan yang signifikan. Masing-masing sekolah dasar menerapakn muatan lokal batik tulis Lasem ditujukan dalam hal dapat melestarikan buadaya batik tulis Lasem sebagai buadaya daerah. Tujuan dari beberapa sekolah dapat dirangkum menjadi beberapa tujuan. Yaitu:

\section{a) Melestarikan budaya batik tulis Lasem}

Sekolah dasar yang memiliki tujuan untuk melestarikan buadaya batik tulis Lasem yaitu seluruh sekolah dasar yang menerapkan muatan lokal batik tulis Lasem. Semua sekolah dasar yang menerapakan mauatan lokal batik ingin melestarikanm batik tulis Lasem. sebagian besar dari tujuan yang ingin dicapai masing-masing sekolah yaitu agar siswa tidak hanya sekedar mengenal namun mengetahui tentang batik dan sejarah batik. Disamping hal tersebut yaitu siswa paling tidak dapat membuat batik tulis Lasem. Serta anak-anak dapat menumbuhkan rasa cinta akan batik dan mau peduli untuk melestarikan batik tulis Lasem.

\section{b) Batik tulis menjadi pekerjaan alternatif}

Terdapat beberapa sekolah yang memiliki tujuan agar siswa ketika dapat membuat batik tulis Lasem, pekerjaan membatik dapat menjadi pekerjaan alternatif bagi siswa. Setealh buadaya batik tulis Lasem diakui oleh UNESCO produksi batik mulai berkembang lagi. Sehingga tujuan ini menjadi pilihan bagi beberapa sekolah. Sekolah yang memiliki tujuan agar batik menjadi pekerjaaan yaitu SD Selopuro 2, SD Karasgede, dan SD Jolotundo.

SD selopuro 2 memiliki tujuan dimana pelaksanaan muatan lokal batik tulis Lasem menjadikan pilihan bagi siswanya agar dapat memiliki kemampuan atau kelebihan sehingga batik ini menjadi pilihan untuk mencari pekerjaan.

Tujuan yang ketiga yaitu menambah ekonomi, maksudnya di SD sini sebagian besar orang tuanya adalah bekerja sebagai membatik. Ketika anak-anak ini mendapat pengetahuan 
muatan lokal batik tulis Lasem maka ketika dirumah anak tersebut dapat membantu orang tuanya membuat batik. Sehingga hal ini dapat membantu ekonomi keluraganya (Hasil wawancara dengan Ibu Sri, 55 tahun, guru, pada tanggal 10 April 2011).

SD Selopuro memiliki keinginan dalam menerapkan muatan lokal batik tulis Lasem pada tingkat sekolah dasar dimana anak-anak ketika bisa membuat batik tulis Lasem dapat mencari uang melalui pekerjaan membatik. Selain hal tersebut anak-anak yang berasal dari keluarga pembatik juga dapat membantu orangtuanya untuk membatik. Terdapatnya muatan lokal di SD Selopuro 2 paling tidak membantu bagi siswa yang berasal dari keluarga pembatik untuk belajar membatik lebih dalam lagi. Sehingga keterampilan yang dimiliki dapat diasah lebih baik lagi..

Bagi SD Karasgede dimana sebagian besar masyarakatnya adalah pembatik maka tujuan dilaksanakan muatan lokal batik tulis Lasem pada tingkat sekolah dasar agar siswa dapat terampil membatik sehingga batik menjadi pilihan untuk mencari pekerjaan. Dari hasil wawancara juga dijelaskan bahwa

melatih keterampilan siswa supaya siswa bisa membantu orang tuanya di rumah karena disini mayoritas warganya adalah pembatik sehingga dengan adanya keterampilan batik di SD anak-anak bisa membantu orang tuanya.(Hasil wawancara dengan Ibu Diyarti, 51 tahun, kepala sekolah, pada tanggal 27 Maret 2011).

Hal ini juga tidak jauh berbeda dengan SD Jolotundo 2, dimana karakteristik sekolah teesebut berada di daerah pinggiran. Tujuan dari SD Jolotundo 2 menerapkan mauatan lokal batik tulis Lasem yaitu praktik membatik batik tulis Lasem dapat menjadi pekerjaan untuk mendapatkan uang. Dari hasil wawancara yaitu :

kadang-kadang anak-anak dipandang perlu ketika anak tidak melanjutkan untuk sekolah ya batik ini menjadi kemampaun bagi anak-anak untuk mendapat pekerjaan. (Hasil wawancara dengan Bapak Juwanto, 50 Tahun, kepala sekolah, pada tanggal 10 April 2011)

\section{Upaya sekolah}

Upayayangdilakukanmasing-masingsekolah dalam mewujudkan terlaksanakannya muatan lokal batik tulis Lasem pada tingkat sekolah dasar tidak terdapat perbedaan dari setiap sekolah dasar di kecamatan Lasem. Hal yang dilakukan dari masing-masing kepala sekolah dasar yaitu mengalokasikan dana BOS (Bantuan Operasional Sekolah) untuk terlaksanakannya muatan lokal batik tulis Lasem. Anggaran dana ini digunakan untuk membeli alat dan bahan membatik batik tulis Lasem. Hal diatas sesuai dengan hasil wawancara dari salah satu sekolah dasar yaitu SD Dorokandang 2 yaitu :

memfasilitasi anak-anak untuk belajar membatik dimana mengalokasikan dana bos untuk membeli alat dan bahan yang digunakan untuk membatik. (Hasil wawancara dengan Ibu Kadarwati, 43 tahun, kepala sekolah, pada tanggal 24 April 2011)

Selain hal tersebut kepala sekolah juga mengusahakan tempat ruangan untuk melakukan praktik membatik batik tulis Lasem. Terdapat beberapa sekolah yang mengusahakan terdapatnya ruangan khusus untuk melakukan praktik membatik batik tulis Lasem. salah satunya yaitu SD Selopuro 2. Hasil dari wawancara yaitu :

Saya sekarang ini masinh mengusahakan untuk dibuatkan ruangan khusus untuk praktik membatik. Sehingga ketika anakanak melakukan praktik sudah tidak di dalam kelas lagi. (Hasil wawancara dengan ibu Sri, 55 tahun, guru, pada tanggal 10 April 2011).

Materi atau bahan ajar muatan 
lokal batik tulis Lasem yang di sampaikan pada siswa tingkat sekolah dasar dibagi menjadi tiga kelas. Masing-masing sekolah memberikan materi muatan lokal batik tulis Lasem dimulai pada kelas empat sampai kelas enam. Materi batik tulis Lasem yang disampaikan masing kelas memiliki kadar materi yang berbeda beda.

Buku ajar muatan lokal batik tulis Lasem dibuat oleh beberapa orang yang di tunjuk oleh Dinas Pendidikan Kabupaten Rembang. hasil wawancara dengan $\mathrm{Bu}$ Diarti yaitu:

Dalam membuat buku ajar batik tulis Lasem pemerintah menunjuk beberapa orang yang dianggap memiliki kemampuan mengetahui sejarah batik dan memiliki kemampuan untuk membuat batik tulis Lasem. jumlah yang membuat terdapat 6 oarng pada waktu itu mas. Saya tidak tahu bagamana mekanisme penunjukan orang-orang yang dipercaya untuk membuat bahan ajar. Enam orang ini berasal dari beberapa kecamatan di Kabupaten Rembang. untuk Lasem sendiri setahu saya ada dua orang yaitu saya sendiri dan ibu Heni Binawati, dia sekarang Kepala sekolah SD Dorokandang 1. Enam orang ini dibagi menjadi 2, masing-masing 2 orang dipercaya untuk membuat bahan ajar kelas empat. Untuk saya kebagian kelas lima. Dari masing-masing tim kemudian menyerahkan hasilnya kepada Dinas Pendidikan Kabupaten Rembang. (Hasil wawancara dengan Ibu Diarti, 51 tahun, kepala sekolah, pada tanggal 27 Maret 2011).

Dalam pembuatan buku bahan ajar muatan lokal batik tulis pemerintah menunjuk beberapa orang yang dianggap memiliki kemampuan mengetahui sejarah atau asal muasal batik tulis Lasem dan memiliki kemampuan untuk membuat batik tulis Lasem. pada waktu itu terdapat enam orang yang ditunjuk oleh pemerintah. Enam orang yang ditunjuk oleh pemerintah beresal dari beberapa kecamatan yang terdapat dikabupaten Rembang. Ibu Diarti mendapat tugas untuk membuat bahan ajar muatan lokal batik tulis Lasem kelas empat dan lima sekolah dasar.

Materi muatan lokal batik tulis Lasem yang diajarkan di kelas empat menurut Ibu Diarti :

Materi batik tulis Lasem yang disajikan di kelas empat merupakan pengetahuan dasar tentang batik tulis Lasem. Materi yang diasjikan pada buku ajar muatan lokal batik tulis Lasem pada kelas lima yaitu tahap selanjutnya dari materi yang telah diajarkan pada kelas IV. Materi ini lebih terfokus pada pengenalan sejarah batik tulis Lasem bagaimana asal-muasalnya dan lebih menekankan pada siswa agar dapat membuat polapola batik tulis Lasem dari kertas yang kemudian ketika telah mahir dapat diteruskan membuat pola batik tulis Lasem pada kain batik sesuai dengan langkah-langkah yang telah dijelaskan pada kelas empat.

Buku bahan ajar muatan lokal batik tulis Lasem ini juga memiliki standar kompetensi dan kompetensi dasar yang harus dicapai oleh siswa kelas lima. Standar kompetensi dan kompetensi dasar muatan lokal batik tulis Lasem pada kelas lima disajikan pada Tabel 1.

Terdapatnya standar kompetensi dan kompetensi dasar pada buku ajar muatan lokla batik tulis Lasem pada tingkat sekolah dasar kelas lima maka materi yang akan dijelaskan terdapat enam bab. Bab 1 yaitu menjelaskan pengertian batik tulis Lasem, bab 2 menjelaskan tentang sejarah batik tulis Lasem, bab 3 menjelaskan ragam hias batik tulis Lasem, bab 4 menjelaskan warna batik tulis Lasem, bab 5 menjelaskan pola dasar ragam hias batik, bab 6 proses membatik.

\section{Pelaksanaan di Sekolah}

Pelaksanaan pembelajaran muatan lokal batik tulis Lasem pada tingkat sekolah dasar di kecamatan Lasem yaitu : 


\section{1) $S D$ Dorokandang 2}

Pelaksanaan muatan lokal batik tulis Lasem di SD Dorokandang 2 dimulai dengan kelas empat. Muatan lokal batik tulis Lasem sudah di laksananakan di SD Dorokandang mulai beberapa tahun yang lalu. Guru yang sekarang mengajar muatan lokal batik tulis Lasem di SD Dorokandang Ibu Jarwati.

Pelaksanaaan muatan lokal batik tulis Lasem kelas empat pada SD Dorokandang 2 untuk semester 1 hanya dalam bentuk pengenalan. Ibu Jarwati tidak membutuhkan persiapan yang begitu banyak ketika mengajari anak-anak kelas empat dalam belajar muatan lokal batik tulis Lasem.

Kelas empat semester satu muatan lokal batik tulis Lasem lebih pada pengenalan anak tentang batik dan bagaimana sejarah batik serta alat dan bahan yang digunakan untuk membatik. Materi ini sesuai dengan buku ajar muatan lokal batik tulis Lasem yang diberikan oleh Dinas Pendidikan Kabupaten Rembang. (Hasil wawancara dengan Ibu Jarwati, 41 tahun, Guru pada tanggal 24 April 2011)

Muatan lokal batik tulis Lasem kelas empat mulai dikenalkan dengan materi batik secara umum dan bagaimana sejarah batik tulis Lasem. bahan ajar yang digunakan telash disediakan oleh pemerintah kabupaten Rembang. Pelaksanaan pembelajaran yang dilakukan oleh Ibu Jarwati yaitu tidak berbeda dengan pembelajaran mata pelajaran yang lain. Pembelajaran muatan lokal yang berkaitan dengan materi yang harus dikuasai oleh siswa dilakukan dengan langkah yaitu menjelaskan terlebih dahulu kepada siswa setelah itu baru memberi catatan pada siswa. Hal ini sesuai dengan hasil wawancara dengan Ibu Jarwati:

namun untuk semester satu saya hanya menerangkan tentang batik dan sejarah batik tulis Lasem mas. Saya lebih banyak bercerita ketika mengajarkan bab ini. Sebelum memasuki materi sejarah batik untuk pengenalan tentang batik saya membawa beberapa motif batik untuk saya perkenalkan dengan anak-anak bahwa ini lo batik tulis Lasem. Karena saya dulu pernah bekerja di pengusaha batik tiga berlian maka saya sedikit banyak tahu tentang sejarah batik sehingga ketika saya bercerita kepada anak-anak kelas empat tidak mengalami kesulitan. (Hasil wawancara dengan Ibu Jarwati, 41 tahun, Guru pada tanggal 24 April 2011)

Banyak berbagai cara yang dilakukan oleh Ibu Jarwati dalam pembelajaran muatan lokal batik tulis Lasem. Langkah-langkah tersebut dilakukan agar siswa lebih paham mengenai apa yang disebut batik tulis Lasem. Pemanfaatan media sangat membantu Ibu Jarwati dalam menjelaskan materi batik tulis Lasem kepada siswa. Selain hal tersebut juga mendekte materi batik tulis Lasem kepada anak agar memiliki catatan untuk dipelajari siswa.

Dalam hal pemberian tugas untuk mata pelajaran muatan lokal batik tulis Lasem pada tingkat kelas empat di SD Dorokandang 2 Ibu Jarwati hanya memberikan tugas tertulis. Lebih banyak meteri pengetahuan yang harus diketahui oleh siswa maka Ibu Jarwati lebih banyak memberikan soal latihan. Memberikan soal latiahan kepada anak-anak Ibu Jarwati hanya meberikan dua kali latihan soal yaitu pada MID semeseter dan ulangan semester satu. Ibu Jarwati tidak pernah memberikan tugas untuk dikerjakan dirumah.

Pelaksanaan muatan lokal batik tulis Lasem pada kelas empat semester dua Ibu Jarwati hanya menerangkan pola-pola atau ragam hias batik tulis Lasem.

Untuk semester dua saya hanya menerangkan motif dan ragam hias batik tulis Lasem untuk kelas empat. Alat dan bahan yang sebenarnya terdapat di kelas empat semester 1 saya jelaskan di kelas lima. Untuk kelas lima kan sudah mulai masuk praktik membuat batik maka skalian saya jelaskan alat dan bahannya. 
(Hasil wawancara dengan Ibu Jarwati, 41 tahun, Guru pada tanggal 24 April 2011

Pembelajaran batik tulis Lasem yang dilakukan oleh Ibu Jarwati yaitu menjelaskan berbgai macam ragam hias batik tulis Lasem. Namun materi yang sebenarya terdapat di kelas empat dijelaskan di kelas lima. Ibu Jarwati memiliki alsan bahwa agar anakanak lebih mudah memahami ketika setelah dijelaskan langsung melakukan praktinya agar anak-anak tidak mudah lupa apa yang telah dipelajari. Langkah yang dilakukan ini merupakan cara untuk mengantisipasi ketika telah melakukan praktik membatik banyak anak yang tidak cepat lupa apa yang telah dilakukan.

Pembelajaran ragam hias batik tulis Lasem ini dilakukan Ibu Jarwati dengan berbagai cara. Selain menggunakan referensi yang dimiliki perusahaan batik tulis Lasem juga menggunakan buku bahan ajar. Ragam atau motif yang dijelaskan adalah ragam hias batik tulis Lasem yang masih tahap dasar. Tingkat kerumitan dalam menggambar belum akan dialami siswa ketika praktik membuat ragam hias batik tulis Lasem.

\section{Motif dan ragam hias batik tulis Lasem saya jelaskan dengan menggunakan buku ajar dan saya tambahi dengan meminjam buku yang dimiliki perusahaan batik tiga berlian. Anak- anak saya jelaskan atau saya kenalkan beberapa motif ragam hias batik tulis Lasem dengan membawa beberapa contof motif. (Hasil wawancara dengan Ibu Jarwati, 41 tahun, Guru pada tanggal 24 April 2011)}

Pembelajaran muatan lokal batik tulis Lasem semester dua pada kelas empat lebih di tekankan pada kegiatan praktik. Anak-anak mulai dikenalkan berbagai macam ragam atau motif batik tulis Lasem. Anak-anak kelas empat disuruh untuk menggambar motif yang telah di ajarkan oleh Ibu Jarwati. motif-motif yang diajarkan dambilkan dari bahan ajar dimana diambil gambar yang paling mudah terlebih dahulu.
Ibu Jarwati memberikan contoh motif bunga ceplok atau motif tumbuhan latohan. Motif ini merupakan motif yang mudah untuk di gambarkan

Setelah saya gambar di papan tulis saya baru menjelaskan ini misalnya anakanak ini motif kembang ceplok. Motif kembang ceplok adalah motif jawa. Cara menggambarkannya adalah dimulai dengan membuat lingkaran ditengahnya kemudan membuat setengah lingkaran yang berada di sisi lingkaran tengah. Setelah saya selesai mencontohkan menggambar pada anak-anak kemudian anak-anak saya suruh menggambar motif yang telah saya contohkan di kertas gambar.( Hasil Wawancara dengan Ibu Jarwati, 41 tahun, Guru pada tanggal 24 April 2011)

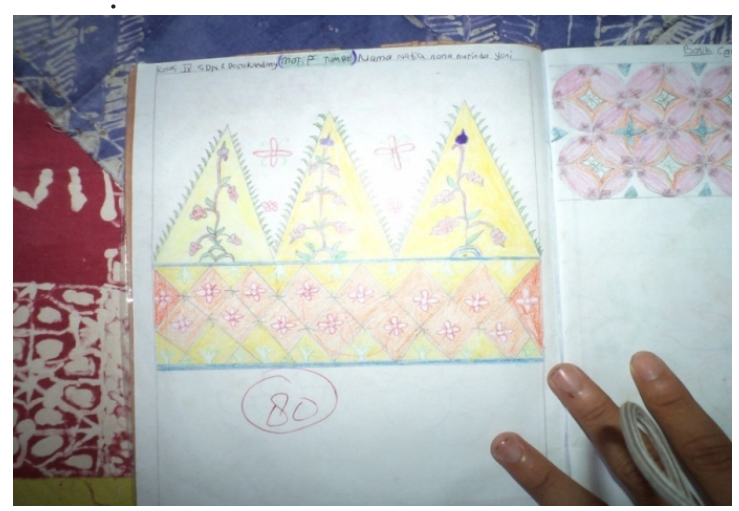

Sumber : Data Primer, hasil Penelitian, 2011 Gambar 1. Motif Bunga Ceplok hasil gambar siswa

Pelaksanaan muatan lokal batik tulis Lasem pada tingkat kelas lima sekolah dasar SD Dorokanang 2 semester satu dimulai pada pengenalan Ragam hias Batik Tulis Lasem. Sebenaranya ragam hias batik tulis Lasem sudah diterangkan di kelas empat, ragam hias yang diterangkan di kelas lima ini merupakan tambahan ragam hias agar siswa lebih mengenal berbagai ragam hias batik tulis Lasem. Terdapat perbedaan ragam hias yang diajarkan di kelas empat dan kelas lima, perbedaan ini terlihat pada kerumitan bentuk motif yang diajarkan di kelas lima. 
Setiap pertemuan motif yang diajarkan berbeda-beda.

Materi selanjutnya yaitu pengenalan

alat dan bahan serta bagaimana penggunaanya. Sebenarnya meteri ini ada di buku bahan ajar kelas empat, namun sama Ibu Jarwati baru diajarkan pada kelas lima semester satu. Terdapat beberapa alat dan bahan yang dijelaskan oleh Ibu Jarwati. pembuatan batik tulis Lasem membutuhkan tiga bahan yaitu kain, malam, dan pewarna, Ibu Jarwati hanya menjelaskan bahan kain dan malam.

Anak-anak lebih saya tekankan bagaimana kegunaan bahan yang digunakan untuk membuat batik tulis Lasem. selain hal tersebut saya juga menjelaskan bagaimana salah satu bahan tersebut digunkan, salah satunya yaitu malam. (Hasil wawancara dengan Ibu Jarwati, 41 tahun, Guru pada tanggal 24 April 2011).

Setelah menjelakan bahan yang digunakan untuk mebuat batik tulis Lasem selanjutnya Ibu Jarwati mulai masuk ke alatalat yang dipakai untuk membatik. Alatalat tersebut yaitu canting, wajan, kompor kecil, gawangan, dingklik, kompor besar, baskom, gledegan. Ibu Jarwati menjelaskan pengertian dari kegunaan alat-alat tersebut dengan membawa alatnya langsung di dalam kelas. Alat tersebut dijelaskan satu persatu dengan memperlihatkan alat tersebut kepada anak-anak kelas lima.

Praktik membatik pada kelas lima dimulai pada semester dua. Mulai masuk semester dua Ibu Jarwati menyiapkan alat dan bahan untuk membatik pada kelas lima. Praktik membatik pada kelas lima dilakukan pada jam pelajaran yaitu 2X35 menit seminggu. Di SD Dorokandang 2 tidak terdapat praktik membuat batik tulis Lasem diluar jam pelajaran. Bahan dan alat membatik semua disediakan oleh sekolahan.

Ketika praktik untuk kelas lima saya menyiapakan alat dan bahan terlebih dahulu sebelum masuk kelas. Kemudian anak-anak saya kondisikan dengan membagi beberapa kelompok. Keterbatasan bahan dan alat untuk membatik yang dimiliki sekolah maka satu kelompok bisa mencapai 5 sampai 6 anak. (Hasil wawancara dengan Ibu Jarwati, 41 tahun, Guru pada tanggal 24 April 2011).

Pembelajaran praktik muatan lokal batik tulis Lasem pada kelas lima SD Dorokandang yaitu dibagi dalam beberapa kelompok. Setiap kelompok terdiri dari lima sampai enam siswa. Keterbatasan alat dan bahan sehingga dalam praktik membatik batik tulis Lasem siswa harus secara bergantian untuk mencoba membuat batik tulis Lasem.

Sebelum memasuki praktik anak-anak akan mendapatkan pejelasan terlebih dahulu pada Ibu Jarwati yaitu penjelaan agar anakanak dapat mengikuti arahan sehingga dalam praktik membatik tidak mengalami kesalahan. Apabila ada siswa yang tidak paham maka boleh bertanya terlebih dahulu dan dijelaskan kembali. Dalam praktik muatan lokal batik tulis Lasem siswa akan selalu dibimbing dan diarahkan agar siswa dapat melakukan praktik dengan baik.

Sebelum benar-benar mulai praktik, saya jelaskan beberapa penjelasan terlebih dahulu. Motif yang dipakai anak-anak adalah motif yang mereka suka dimana motif tersebut pernah dibuwat oleh anak-anak pada kelas empat dan kelas lima. Setelah anakanak memilih motif kemudian anakanak mulai menggambar di kain dengan memblat gambar yang pernah digambar dengan karbon. (Hasil wawancara dengan Ibu Jarwati, 41 tahun, Guru pada tanggal 24 April 2011).

Tahap awal dalam praktik membatik batik tulis Lasem yaitu dengan memilih motif batik. Ibu Jarwati memberi kebebasan kepada anak untuk memilih motif untuk digambar. Tahap menggambar Ibu Jarwati telash menyiapkan karbon yang dipakai untuk memblat motif yang telah disipakan. 
Pada tahap ini ibu jaerwati selalu memantau anak-anak untuk selalu berhati-hati dalam menggambar.

Tahap berikutnya yaitu tahap nglengkreng, tahap ini merupakan tahap dimana menorehkan malam pada kain. alat yang digunakan yaitu canting. Bahan yang digunakan yaitu malam. hal-hal yang dilakukan siswa ketika praktik pada tahap ini yaitu harus memanasi malam terlebih dahulu sebelum ditorehkan malam pada kain. tahap ini merupakan tahap yang sulit dan sering membuat anak-anak melakukan kesalahan. Banyak materi yang dapat dijelaskan pada tahap ini seperti bagaimana cara penggunaan canting dan jenis-jenis canting yang dapat dimanfaatkan pada tahap ini.

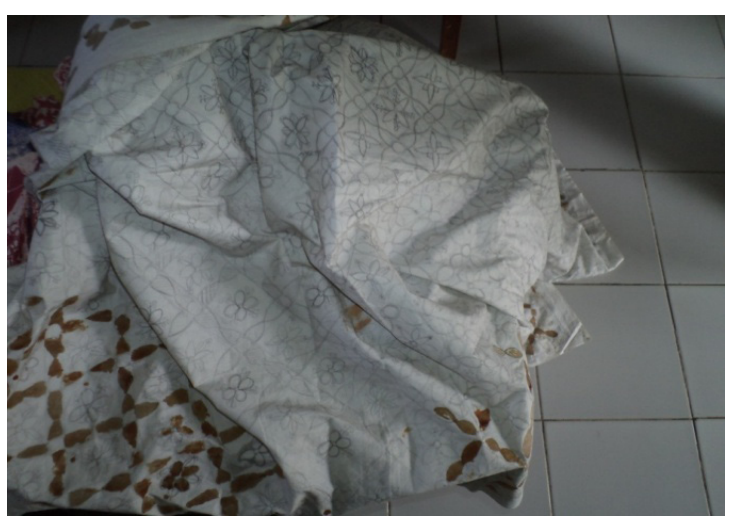

Sumber : Data primer hasil penelitian, 2011

Gambar 2. Hasil tahap nglengkreng kelas 5 SD Dorokandang 2

Setelah selesai anak-anak mulai dengan menorehkan malam yang sudah panas pada motif kain yang telah dia gambar. Langakah ini dilakukan anak-anak secara bergantian karena tidak mungkin enam anak menggambar secara bersamaan. Sebagian ada yang memanasi malam pada kompor dan mengurusi canting yang akan dipakai agar tidak buntu. Praktik ini ketika belum selesai akan dilanjutkan pada pertemuan berikutnya sampai pada anak dapat merasakan bagaimana cara membuat batik tulis Lasem semuanya.

Nerusi merupakan tahap selanjutnya yang harus dilakukan oleh siswa. Tahap ini juga hampir sama dalam pelaksanaannya. Alat dan bahan yang digunakan masih berupa canting dan malam. hal-hal yang perlu diperjhatikan pada siswa yaitu kehatihatian. Tahap nerusi merupakan pembuatan motif yang sama pada sisi sebaliknya. Ketika terjadi kesalahan maka akan membuat motif tersebut tidak sama. Pada tahap ini Ibu Jarwati selalu memberi bimbingan dan pengarahan kepada anak agar anak-anak tidak sering mengalami kesalahan dan teramppil dalam membuat.

Tahap isen-isen merupakan tahap selanjutnya dari proses membatik. Tahap ini merupakan tahap yang mudah namun juga kadang susah. Tahap isen-isen merupakan tahap monorehkan malam pada kain untuk mempertegas gambar. Siswa dalam melakukan praktik ini juga perlu kehatihatian.alat yang dipakai dan bahan yang digunakan masih sama dengan tahap selanjutnya. Tahap ini tidak membutuhkan waktu yang lama seperti tahap yang lainnya. Hanya sekali pertemuan tahap ini dapat selesai

Pelaksanaan muatan lokal batik tulis kelas enam yaitu hanya melanjutkan praktik membatik yang dilakukan pada anakanak yang belum selesai ketika dilakukan pada semester dua. Materi yang berupa penegtahuan batik dan sejarah batik tulias Lasem yang sesuai dengan buku ajar tidak lagi dijelaskan pada anak-anak. Hasil kain batik yang telah dibuat oleh siswa yang baru selesai tahap nglengkreng yaitu sebagai berikut.

Proses mewarnai dilakukan oleh anakanak sendiri yaitu anak-anak kelas enam. Ibu Jarwati dalam proses mewarnai hanya memberikan pengarahan pada anak-anak yang kan melakukan pewarnaan kain batik tulis hasil buatannya. Proses pewarnaan dapat dilakukan dalam sekali pewarnaan dalam satu pertemuan. Namun sebelum dimulai pewarnaan atau sebelum jam pelajaran muatan lokal batik tulis dimulai anak-anak sudah disuruh untuk menyiapkan kompor besar dan baskom untuk memanasi air dan memberikan warna pada air yang mendidih. Mulai masuk jam pelajaran baru anak-anak dibimbing sama Ibu Jarwati untuk memberikan pewarnaan pada kain dengan mencelupkan kain pada pewarna yang terdapat pada air di dalam baskom. 
Proses selanjutnya yaitu melorot. Melorot ini merupakan tahapan selanjutnya ketika proses pewarnaan telah dilakukan. Proses melorot ini juga hampir sama dengan proses pewarnaan. Yaitu menyiapkan air mendidih untuk merebus kain yang telah diwarnai. Tujuannya yaitu melunturkan malam yang ada pada kain sehingga akan kelihatan motif batik tulis Lasem yang bagus. Proses melorot ini dapat dilakukan dalam sekali pertemuan tentunya yang melakukan adalah anak-anak kelas enam dengan arahan Ibu Jarwati.

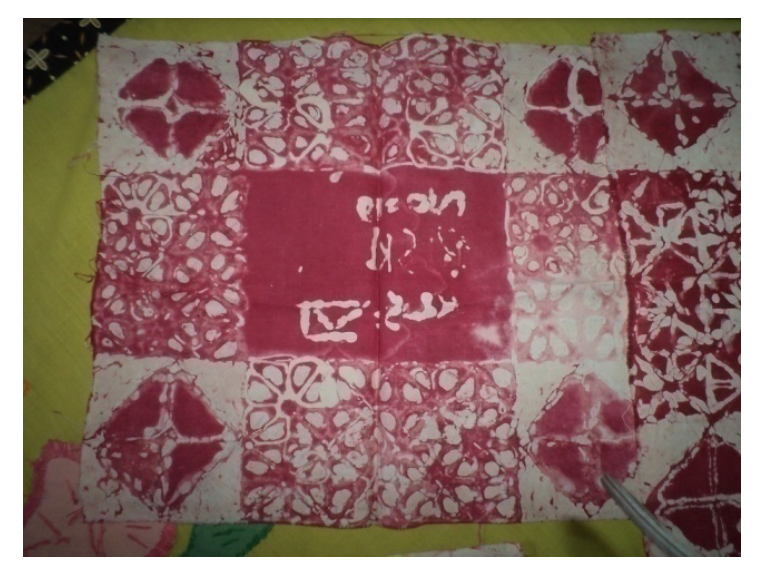

Sumber : Data primer, hasil penelitian, 2011 Gambar 3. hasil kain batik yang dibuat oleh anak-anak kelas enam SD Dorokandang 2

Praktik membatik ini pada kelas enam juga dijadikan sebagai ujian praktik kelas enam. Materi yang diujikan pada anakanak kelas enam SD Dorokandang adalah proses nglengkreng yaitu motif yang telah digambar pada kain kemudian digambar lagi menggunakan malam. Setiap anak maju satu persatu untuk ujian ini secara bergantian.

\section{2) SD Jolotundo 2}

Pelaksanaan muatan lokal batik tulis Lasem pada SD Jolotundo 2 juga diterapkan mulai pada kelas empat sampai pada kelas enam. Materi-materi yang disampaikan tidak terdapat perbedaan dengan sekolahsekolah lain yang juga melaksanaknnya yaitu menggunakan buku bahan ajar muatan lokal batik tulis Lasem yang dari Dinas Pendidikan. namun untuk SD Jolotundo 2 juga memanfaatkan media lain seperti internet.
Pelaksanaan muatan lokal batik tulis Lasem saya menggunakan bahan ajar dari dinas mas. Namun kadang kala saya juga mencari bahan dari internet sekedar untuk mencari-cari motif agar anak-anak mengenal berbegai macam motif. (Hasil wawancara dengan Ibu Nur, 26 tahun, guru pada tanggal 10 April 2011).

Setiap pertemuan Ibu Nur tidak membuat silabus dan RPP dalam pembelajaran muatan lokal. Menurut Ibu Nur pembelajaran muatan lokal yang dilakukannya selama ini lebih ditekankan pada pembelajaran Praktik. Pelaksanaan pembelajaran Ibu Nur juga tidak terpaut pada urutan materi. Misalnya pelaksanaan muatan lokal batik tulis Lasem pada kelas empat. Ibu Nur menjelaskan materi tentang batik tulis juga sekalian menjelaskan motif batik tulis. Ibu Nur menjelaskan materi tentang batik itu juga membawa beberapa contoh batik tulis Lasem sehingga Ibu Nur juga menjelaskan bahwa ini motif batik dan ini motif batik apa. Selain hal tersebut ibu Nur juga mengenalkan berbagai macam alat dan bahan yang digunkan untuk membuat batik tulis Lasem.

Pemberian tugas pada anak-anak kelas empat juga tidak terlalu banyak. Ibu Nur juga menyesuaikan dengan materi pada semester satu untuk kelas empat. Betuk tugas pada materi semester satu kelas empat yaitu ujian terteulis atau soal A B dan C. Soal ini biasa diberikan pada saat ujian tengah semester dan semesteran.

Praktik membuat pola atau motif ragam batik tulis Lasem dimulai pada semester dua. Setiap pertemuan Ibu Nur mengajari satu motif batik tulis Lasem. Motif-motif yang diajarkan Ibu Nur berdasarkan pengalaman pribadi, karena pada masa kecil Ibu Nur merupakan dari keluarga membatik. Banyaknya pengalaman yang di dapat sehingga memepermudah Ibu Nur mengajar muatan lokal batik tulis Lasem.

Ketika praktik membatik pada kelas empat awalnya saya hanya 
mengenalkan motif-motif yang saya gambar di papan tulis. Setelah selesai baru anak-anak saya suruh untuk menggambar motif batik tulis pada kertas manila. Sebenarnya saya ingin langsung mengajak anakanak menggambar langsung di kain. karena keterbatasan biaya dari sekolah akhirnya tidak jadi. (Hasil wawancara dengan Ibu Nur, 26 tahun, guru pada tanggal 10 April 2011).

Gambar-gambar motif yang dibuat oleh anak-anak kelas emapat sayangnya tidak diarsipkan oleh Ibu Nur. Sehingga saya tidak mendapatkan hasil gambar motif yang diajarkan pada anak-anak kelas empat. Namun praktiknya anak-anak menggambar pola atau motif batik tulis Lasem pada gambar buku tulis atau kertas manila.

Memasuki kelas lima pembelajaran muatan lokal batik tulis Lasem diajarkan dengan secara lengkap. Berbeda dengan kelas empat dimana hanya sekedar pengenalan bahwa anak-anak harus mengetahui tentang keberadaan batik tulis Lasem di daerahnya. Muatan lokal batik tulis Lasem pada kelas lima materi yang diberikan mulai pada sejarah batik tulis Lasem secara lengkap dan penjelasan dari beberapa alat dan bahan yang harus dimengerti oleh siswa.

Penjelasan materi batik tulis Lasem terutama sejarah batik tulis Lasem saya lebih bada berecerita kemudian anakanak saya dektekan agar memiliki catatan. Anak-naak kelas lima kadang juga bilang pada saya bu materinya tidak di foto copy. tidak anak-anak kalau saya foto copy nantinya tidak akan kalian baca. (Hasil wawancara dengan Ibu Nur, 26 tahun, guru pada tanggal 10 April 2011).

Ibu Nur menjelaskan kegunaan alat dan bahan yang dipakai untuk membuat batik tulis Lasem dengan membawa alat dan bahan tersebut di dalam kelas. Ketika kelas empat Ibu Nur hanya mengenalkan alat-alat tersebut pada media gambar namun pada kels lima anak-anak dijelaskan kegunaan alat dan bahan yang dipakai untuk membuat batik tulis Lasem dengan Ibu Nur yang mempraktikan bagaimana alatalat dan kegunaan bahan tersebut. Dengan harapan anak-anak dapat cepat lebih paham dan nantinya dapat memlakukan praktik membatik sendiri.

Penjelasan alat-alat dan bahan yang dipakai saya lebih suka dengan membawa alat-alat tersebut secara langsungkemudiansaya mempraktikan beberapa alat yang penting digunakan. Sambil saya meprakltikan saya juga menjelasakn kegunaan alat dan bahan tersebut. (Hasil wawancara dengan Ibu Nur, 26 tahun, guru pada tanggal 10 April 2011).

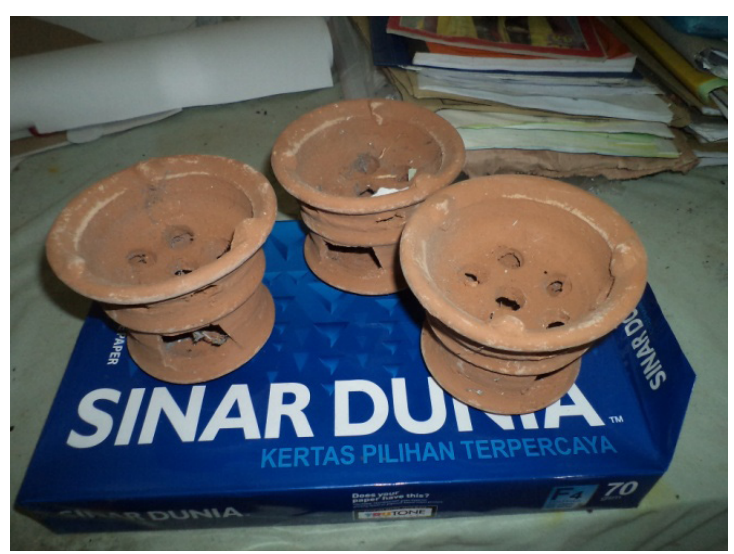

Sumber : Data primer, hasil penelitian, 2011

Gambar 4. kompor untuk memanasi malam dengan menggunakan arang.

Pelaksanaan praktik membatik pada kain baru dilakukan pada kelas lima semester dua. Selama satu semester ini anakanak hanya melakukan praktik membatik mulai dari membuat pola atau motif batik tulis Lasem pada kain dengan menggunakan pensil. Agar praktik ini dapat berjalan dengan baik maka dalam satu kelas dibagai beberapa kelompok. Kelompok ini bukan guru yang menentukan namun anak-anak kelas lima yang meilih kelompok sendiri. Satu kelompok terdiri dari empat orang. Siswa di SD Jolotundo dua tidak pernah banyak, sehingga kelompok tersebut anggotanya tidak terlalu banyak. Langkah awal yang dilakukan anak-anak yaitu membuat pola 
batik tulis Lasem secara bergantian. Pola yang dibuat oleh anak-anak adalah pola yang pernah dibuat oleh anak-anak mulai pada kelas empat.

Anak-anak saya bebaskan untuk memilih motif yang mereka suka untuk menggambarkan pada kain dengan pensil. Ketika menggambar anak-anak juga memanfaatkan bahan kertas karbon untuk memblat gambar yang dahulu pernah digambar. (Hasil wawancara dengan Ibu Nur, 26 tahun, guru pada tanggal 10 April 2011).

Pelaksanaan praktik membatik tulis Lasem tahap selanjutnya yiatu tahap nblengkreng, nerusi, dan isen-isen. Dari ketiga tahap ini bahan dan alat yang digunakan sama. Ibu Nur menjelaskan dan mengarahkan kepada anak-anak selain hal tersebut juga mendampingi anak-anak melakukan praktik ini. Tahap nglengkreng merupakan tahap menorehkan malamm pada kain mori yang telah digambar motif. Pada tahap ini banyak yang harus dipelari anak-anak yaitu seperti bagaimana cara memegang canting yang benar. Anak-anak juga diajari bagaimana melihat malam yang sudah dapat dipakai. Pada tahap ini anakanak melakukan secara bergantian.

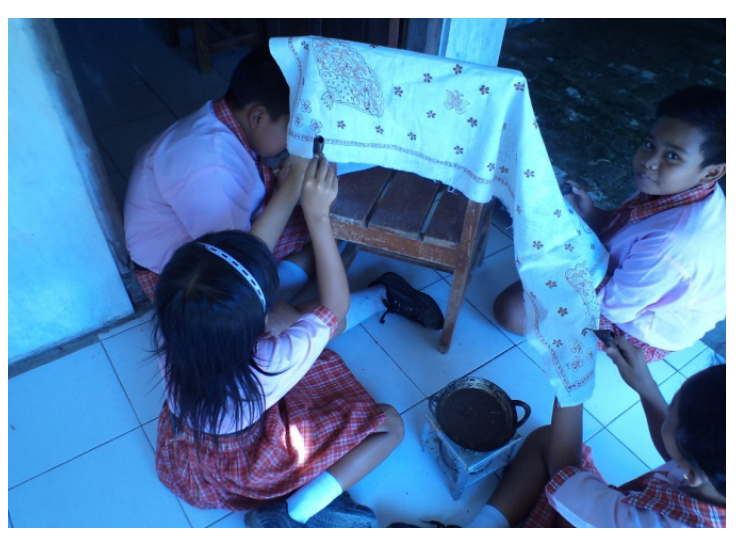

Sumber : Data primer, hasil penelitian, 2011 Gambar 5. Tahap nglengkreng yang dilakukan siswa SD Jolotundo 2

Tahap selanjutnya yaitu tahap nerusi, tahap ini juga masih sama dalam alat dan bahan. Tahap nerusi merupakan tahap lanjutan yaitu membuat pola atau motif yang sama pada sisi sebaliknya. Tahap ini membutuhkan pengarahan agar anak-anak tidak megalami kesalahan. Alat dan bahan yang digunakan masih sama dengan tahap sebelumnya.

Tahap isen-isen merupakan tahap lanjutan dari praktik membatik batik tulis Lasem. tahap ini merupakan tahap dimana mempertegas gambar dengan memberi isenisen malam pada gambar. Tahap ini masing menggunakan malam dan alat canting. Pada tahap ini siswa juga harus berhati-hati dalam penorehan malam. agar tidak mengalami kesalahan dalam memberi isen-isen.

Pelaksanaan muatan lokal batik tulis Lasem pada kelas enam SD Jolotundo 2 yaitu meneruskan praktik membatik dari kelas lima. Pada saat kelas lima tujuannnya yaitu membuat taplak menja dengan motif batik tulis Lasem sehingga untuk kelas enam ini meneruskan tahapan tersebut. Praktik membatik tulis Lasem pada kelas lima yaitu sampai pada tahap nglengkreng dan isen-isen. Langkah selanjutnya yaitu tahap mewarnai dan melorot. Proses ini dilakukan oleh anakanak sendiri dengan bimbingan Ibu Nur. Proses mewarnai ini menggunakan bahan pewarna. Materi ini sudah dijelaskan ibu Nur pada saat kelas lima semester satu. Alat yang dipakai pada saat mewarnai proses membatik yaitu kompor besar dan baskom yang terisis air. Proses pewarnaan ini air yang digunakan harus dalam keadaan masih panas, agar warna yang dapat melekat pada kain ini dapat menyeluruh.

Pada tahap mewarnai kain batik anakanak benar-benar harus saya bimbing. Tahapinimemangkelihatannya mudah namun juga sulit ketika dilakukan anak-anak apalagi baru mulai belajar membatik. Air yang masih panas juga membahayakan bagi anak-anak maka perlu saya arahkan agar anakanak dapat mewarnai dengan baik dan warna dapat menyeluruh. (Hasil wawancara dengan Ibu Nur, 26 tahun, guru pada tanggal 10 April 2011).

Proses pewarnaan selesai yaitu tahap melorot, tahapan ini juga masih 
menggunakan kompor besar untuk memanasi air yang mendidih. Proses melorot harus menggunakan air yang mendidih hal ini dikarenakan agar malam dapat melorot dan hilang dari kain batik. Cara-cara untuk melakukan proses melorot yaitu dengan menyiapkan air mendidih kemudian kain batik tersebut dicelumkan dan diaduk-aduk agar malam yang menempel pada kain lepas. Setelah kain bersih dari malam kemudian kain tersebut diangin-anginkan.

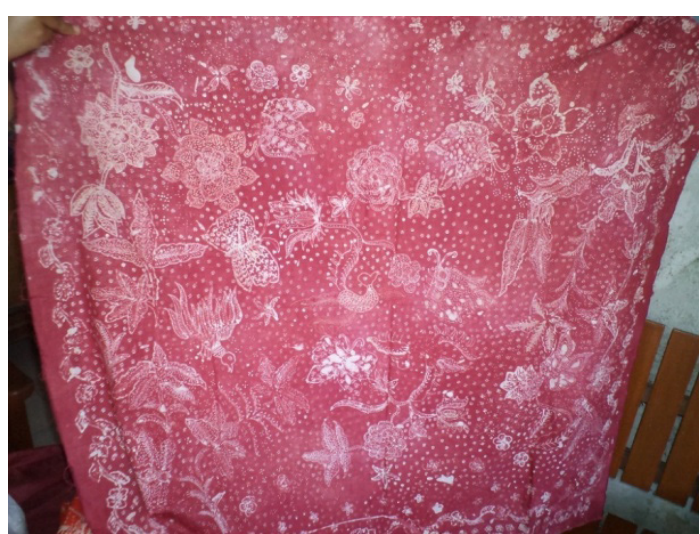

Sumber : data primer, hasil penelitian, 2011

Gambar 6. Hasil batik tulis siswa SD Jolotundo 2

Pada saat kelas enam memasuki semester dua di SD Jolotundo tidak ada praktik membatik lagi. Anak-anak kelas enam mulai mempersipakan menjelang ujian sekolah dan ujian nasional. Namun ujian praktik membtaik juga akan dilakukan oleh anak-anak kelas enam. Ibu Nur melaksannakan ujian membatik pata tahap Nglengkreng yaitu menorehkan malam pada kain yang telah digambar. Penilaiaanya dilihat dari kerapian anak-anak kelas enam menorehkan malam pada motif kain batik.

\section{3. $S D$ Karangturi}

Pelaksanaan muatan lokal batik tulis Lasem di SD Karangturi dimulai mulai kelas empat, lima, dan enam. Guru yang mendapat pelatihan membatik dari Dinas Pendidikan Kabupaten Rembang bernama Ibu Sunarti. Ibu sunartik merupakan guru kelas enam. Pelaksanaan muatan lokla batik tulis Lasem pada SD Karangturi dilaksanakan pada tahu ajaran 2009/2010.
Pengajaran muatan lokal batik tulis Lasem pada kelas empat dipegang oleh guru kelas. Guru kelas ini mengajar pada anak-anak hanya berupa materi pengenalan tentang batik tulis Lasem dan bahan serta alat yang digunakan untuk membuat batik tulis Lasem. Materi yang diajarkan oleh guru kelas empat sesuai dengan buku bahan ajar yang diberikan oleh Dinas pendidikan Kabupaten Rembang. Guru kelas yang mengajar pada kelas empat mengajar muatan lokal batik tulis Lasem hanya kelas empat pada semester satu.

Pelaksannaan muatan lokal batik tulis Lasem pada kelas mepat saya serahkan pada guru kelas. Karena kelas empat lebih pada pengenalan muatan lokal pada anak-anak tentang batik dan sejarah batik. Namun ketika masuk ke praktik nanti saya yang mengajar. Baik praktik membatik kelas empat dan kelas lima, untuk kelas enam kan memang sudah saya pegang. (Hasil wawancara Ibu Muslimah, 50 tahun, pada tanggal 11 April 2011).

Pembelajaran muatan lokal batik tulis Lasem pada kelas empat semester satu tidak jauh berbeda dengan sekolah-sekolah lain. Pengenalan batik dilakukan dengan cara bercerita, keterkaitan dengan sejarah batik tulis Lasem agar anak-anak pada mengenal dan mengetahui dan akhirnya dapat peduli maka materi kelas empat lebih pada pengenalan kepada anak-anak. Habis anakanak mendapat penjelasan kemudian guru kelas mendektekan materi agar anak-anak tidak lupa dengan materi yang dijelaskan. Bentuk tugas dan penilaian juga sama dengan mata pelajaran lainnya yaitu masih menggunakan latihan soal. Latihan soal ini diberikan ketika saat ujia tengah semester dan pada saat semesteran.

Pada saat memasuki semester dua kelas empat baru, mendapat pengenalan ragam hias batik tulis Lasem. mulai pngenalan ragam hias batik tulis Lasem baru ibu Sunartik yang mengajar materi tersebut. Latar belakang dari ibu sunartik yang memiliki pengalaman dan masih bisa 
membatik sampai sekarang sehingga Ibu Sunarti tidak mengalami kesulitan dalam menjelaskan berbagai macam ragam hias batik tulis Lasem.

Praktik membatik yang dilakukan pada kelas empat yaitu masih berupa ragam hias batik tulis Lasem yang dasar atau mudah dipelajari, misalnya motif kupukupu yang diberi hiasan disekelilingnya yaitu bunga ceplok. Praktik membatik pada kelas empat yaitu menggambar motif dengan pensil pada kertas gambar. Namun penenliti pada saat datang ketempat penelitian tidak mendapatkan dokumnetasi yang memperlihatkan hasil gambar siswa yang masih dikertas. Gambar-gambar hasil karya anak-anak tidak dikumpulkan namun dibawa oleh anak-anak masing-masing setelah dinilai.

Praktik membatik pada kelas empat yaitu saya menggambar motif di papan tulis kemudian di contoh pada anak-anak pada kertas gambar. Awal praktik saya memberika motif yang mudah, ketika anak-anak udah selesai pertemuan selanjutnya saya memberikan contoh motif yang lain. Katika anak-anak menggambar juga saya dampingi sambil saya menjelaskan bahwa ini motif apa. Praktik ini saya berikan selama satu semeter. (Hasil wawancara Ibu Muslimah, 50 tahun, pada tanggal 11 April 2011)

Pelaksanaan muatan lokal batik tulis Lasem pada kelas lima semeter satu juga sama dengan kelas empat. Pada awalnya dipegang oleh guru kelas yang mengajar pada kelas lima. Materi muatan lokal batik tulis Lasem yang diberikan berasal dari buku bahan ajar. Perbedaan dari kelas empat, materi pada kelas lima lebih mendalam tentang pengetahuan batik dan sejarah batik tulis Lasem. materi alat dan bahan tidak hanya sebatas pengenalan namun diberikan penjelasan bagaimana kegunaan alat dan bahan untuk membuat batik tulis Lasem. Pada semester satu kelas lima tidak hanya pembelajarannya materi saja namun ada praktik membatik yaitu membuat pola batik pada kertas. Sehingga penilaian pada kelas lima semester satu tidak hanya latihan soal namun juga nilai di ambil dari praktik.

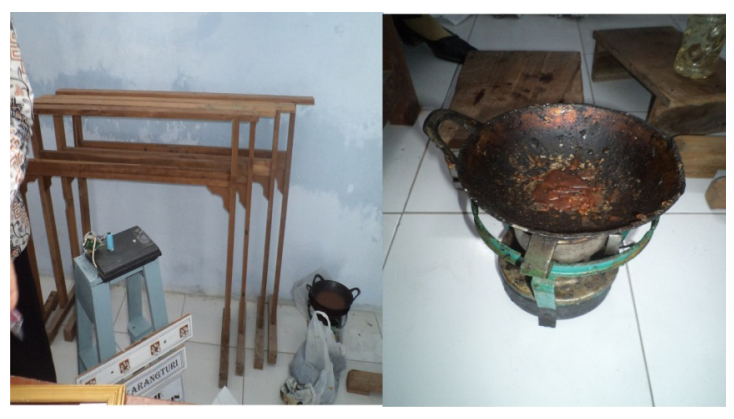

Sumber : data primer, hasil penelitian, 2011

Gambar 7. Alat membatik SD Karangturi

Praktik membatik pada kelas lima semester satu sudah saya coba menggmbar motif bataik tulis Lasem pada kertas namun menggunakan malam. Ketika praktik ini dilakukan saya sekalian menjelaskan bagaimana malam itu sudah bisa digunakan atau belum, bagaimana memegang canting yang benar, bagamana cara menorehkan canting agar malam tidak mlobor (Hasil wawancara Ibu Muslimah, 50 tahun, pada tanggal 11 April 2011)

Praktik membatik batik tulis Lasem pada semester satu sudah ibu Muslimah lakukan yaitu dengan memberikan praktik menorehkan malam pada kertas yang telah siswa gambar. Pada tahap ini anak-anak dilatih oleh ibu Muslimah untuk belajar begaimana cara memegang canting yang benar dan bagaimana cara menorehkan malam yang benar. Gambar yang dikasih malam pada anak-anak merupakan hasil gambar siswa yang menggunakan pensil pada kertas gambar.

Pelaksanaan muatan lokal batik tulis Lasem pada kelas lima semester dua Ibu Muslimah mulai mempersiapkan anak-anak untuk praktik membatik pada kain. praktik membatik pada kain ini Ibu Muslimah memiliki tujuan yang ingin dicapai yaitu membuat seragam batik dari hasil anak-anak sendiri. Setiap anak-anak kelas lima membuat batik untuk dijadikan seragam sekolah dan 
itu anak-anak kelas lima membuat sendiri dengan arahan dari Ibu Muslimah.

Pada tahap membatik pada kain anakanak sudah pada mahir membuat pola batik pada kain. Membuat pola pada sehelai kain putih menggunakan pensil dan kertas karbon tidak membuat anak-anak mengalami kesulitan. Di dalam membuat pola batik tulis pada kain anak-anak SD Karangturi membuthkan waktu kurang lebih dua sampai tiga kali pertemuan. Dalam membuat pola dengan pensil butuh langkah kehati-hatian agar pola yang digambar tidak megalami kesalahan. Rasa sabar pada anaka-anak memang dilatih pada tahap ini.

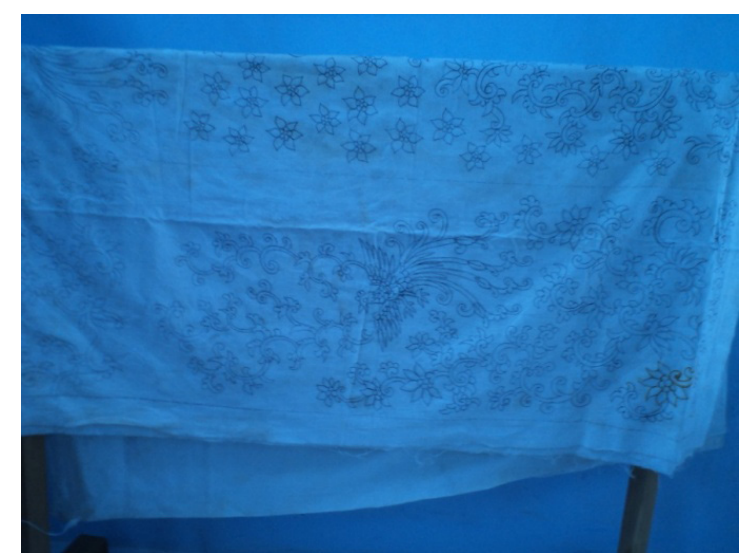

Sumber : Data primer, hasil penelitian, 2011 Gambar 8. kain batik hasil siswa yang masih di gambar dengan pensil.

Tahap selanjutnya yaitu nglengkreng, tahap ini anak-anak mulai menorehkan malam dengan menggunakna canting pada kain. Ibu Sunartik mulai mengarahkan agar pada tahap ini tidak mengalami kesalahan dalan pembuatan batik tulis Lasem. Anakanak dibimbing satu persatu, ketika ada anak yang bisa maka disuruh untuk membantu temannya yang belum bisa dalam membuat pola batik menggunakan malam pada kain.

Pada tahap nglengkreng saya benerbener mengarahkan pada anak-anak agar tidak melakukan kesalahan dalam menorehkan malam pada pola yang telah dibuat sebelumnya. Bagi anak yang sudah bisa maka saya suruh untuk membantu temannya ketika temannya mengalami kesulitan. Pada praktik nglengkreng saya hanya membutuhkan dua sampai tiga kali pertemuan. (Hasil wawancara Ibu Muslimah, 50 tahun, pada tanggal 11 April 2011)

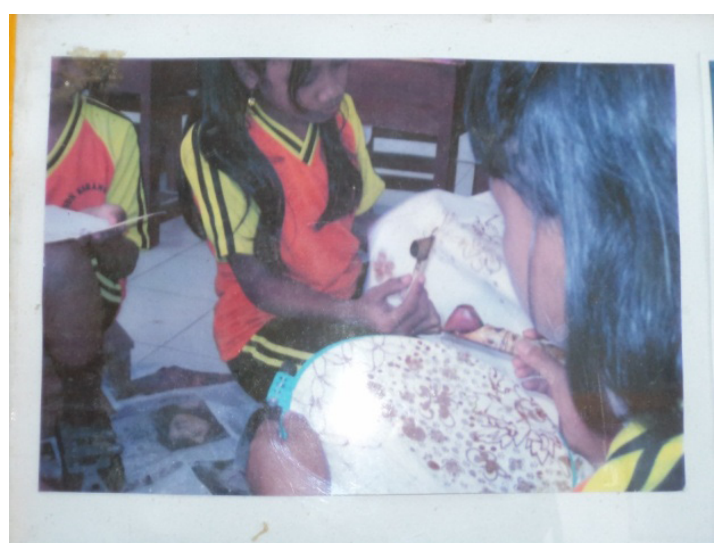

Sumber : Dokumen SD Karangturi

Gambar 9. proses anak-anak sedang melakukan tahap nglengkreng.

Ibu Muslimah lebih memilih untuk melanjutkan praktik meneruskan hasil praktik dari kelas lima. Kelas enam semester satu praktik membatik hanya dilakukan sebentar, karena anak-anak kelas enam akan mengikuti persiapan menjelang ujian nasional. Praktik yang dilakukan adalah tahap nerusi, tahap ini merupakan lanjutan dari nglengkreng. Tidak membutuhkan waktu yang lama dalam proses nerusi, karena motif yang digambar sama yaitu memberi malam pada kain baliknya dengan mengikuti pola yang telah dibuat sebelumnya.

Tahap yang terakhir yaitu tahap isenisen. Tahap ini merupakan tahap dimana menorehkan malam agar mempertgeas motif atau ragam hias batik tulis Lasem. tahap ini juga tidak membutuhkan waktu yang lama. Alat dan bahan yang digunkana juga masih sama dengan tahap sebelumnya. Tahap ini memang butuh ketelitian sehingga anak-anak selalu diberi arahan agar tidak salah menutup pola atau motif ragam hias batik tulis Lasem menggunakan malam. 


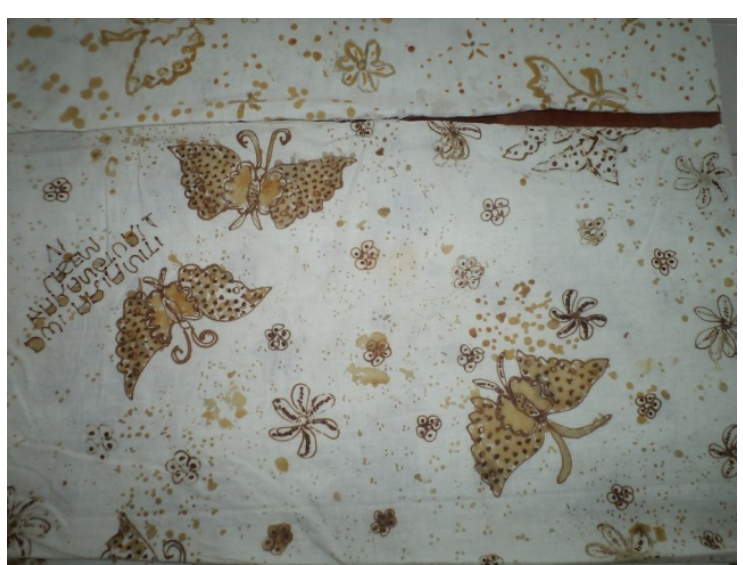

Sumber : Data primer, hasil penelitian, 2011

Gambar 10. Hasil kain batik dari tahap isenisen.

Gambar diatas adalah hasil dari praktik membatik yang dilakukan oleh siswa $\mathrm{Sd}$ Karangturi. Motif yang digambar oleh siswa SD karangturi adalah motif kupu-kupu. Kain batik ini nantinya akan dipakai oleh siswa sebagai seragan sekolah Sd karangturi.

Proses pewarnaan untuk sekolah SD Karangturi di pasrahkan pada pengusaha batik. Biaya untuk membeli bahan pewarna yang mahal sehingga dari pihak sekolah memberikan keputusan untuk meminta bantuan pada pengusaha batik agar tidak mengeluarkan biaya yang banyak. Pelaksannaan muatan lokal batik tulis Lasem menggunakan dana Bantuan Operasional Sekolah sehingga pelaksanaannya juga memperhitungkan terhadap dana..

Pada saat SD Karangturi mengikuti perlombaan batik tulis Lasem di tingkat Kabupten Rembang yang dia adakan oleh Dinas Pendidikan Kabupaten Rembang. Proses pembuatan batik tulis Lasem mulai dari membuat pola di kain sampai dengan pewarnaan dan mlorot dilakukan sendiri. Dalam perlombaan biasanya SD Karangturi mengirim beberapa anak untuk mengikuti perlombaan batik.

\section{SD Karasgede}

Pelaksanaan muatanm lokal batik tu; lis Lasem pada SD Karasgede dilaksananakan pada kelas empat samapi kelas enam. Guru yang mengajar mata pelajaran muatan lokal batik tulis Lasem adalah kepala sekolahnya sendiri. Pada saat pembelajaran muatan lokal batik tulis Lasem ibu kepala sekolah dibantu dengan guru muda dan ketika ibu kepala sekolah ada agenda lain maka yang mengajar muatan lokal batik tulis Lasem adalah guru muda.

Untuk muatan lokal batik di SD Sini yang mengajar saya, karensa disini yang bisa membuat batik adalah saya. Namun ketika saya tidak bisa mengajar keran ada agenda kepala sekolah ya saya suruh guru muda untuk mengajar muatan lokal bataika agar kelas tidak kosong. (Hasil wawancara dengan Ibu Diyarti, 51 tahun, kepala sekolah, pada tanggal 27 Maret 2011)

Pelaksanaan muatan lokal batik tulis Lasem pada tinggkat kelas empat di SD Karasgede hanya sebatas pengenalan tentang batik pada anak-anak. Materi yang diajarkan sesuai dengan buku bahan ajar dari Dinas Pnedidikan Kabupaten Rembang. Materimateri yang dijelaskan yaitu sejarah batik, mengenalkan pola batik, membuat motif batik pada kertas dan menjelaskan alat dan bahan yang digunakan untuk membuat batik tulis Lasem. Materi pengenalan sejarah batik tulis Lasem di kelas empat hanya diceritakan pada Ibu Diyarti dan anak-anak kelas empat mendengarkan.

Materi selanjutnya yaitu mengenalkan pola atau motif batik pada anak-anak. Pengenalan pola batik dilakukan Ibu Diryati di dalam kelas dengan menggambar pola di papan tulis. Ibu Diryati menggambar pola pada papan tulis dan menjelaskan bahwa ini pola atau motif apa.

Pelaksanaan muatan lokal batik tulis Lasem disini lebih banyak praktiknya dari pada materi, ketika praktik baru saya sambil jelaskan. Ketika mengajar pola batik maka saya menggambar terlebih dahulu baru saya jelaskan pada anak-anak ini pola apa. Untuk kelas empat saya masih pada tahap pengenalan. Pada saat pengenalan saya tidak kesulitan untuk mengahadapi anak-anak kelas empat. Sebenarnya 
mereka sudah pada tahu tentang batik karena ada siswa yang keluarganya pembatik dan ada tetangganya yang membatik. Batik tulis Lasem untuk siswa SD Dorokandang sudah tidak asing bagi mereka. (Hasil wawancara dengan Ibu Diyarti, 51 tahun, kepala sekolah, pada tanggal 27 Maret 2011)

Masuk semester dua anak-anak sudah mulai mengenal beberapa motif batik tulis Lasem. Ibu Diryati mulai mengajarkan pada anak-anak kelas empat untuk membuat pola di kertas. Awal-awal pembelajaran membuat pola dikertas masih menggunakan kertas gambar. Motif yang digambar anak-anak masih berupa motif dasar batik dan biasanya digunakan untuk hiasan pola utama, motifmotif yang diajarkan pada anak-anak yaitu bintang, latohan, motif lurik, bunga ceplok dan lain-lain. Ada beberapa anak yang sudah mahir menggambar pola batik dan ada juga yang belum bisa menggambar motif batik. Ibu Daryati dalm praktik membatik tulis Lasem mengajari pada anak-anak secara personal. Ibu Diryati mengajari anak satu persatu dengan cara berkeliling. Namun ketika terdapat anak yang sudah bisa diminta sama ibu Diryati untuk ikut membatu temannya yang belum bisa menggambar motif dengan benar.

Nilai yang diambil untuk menilai anak-anak pada saat praktik membatik ibu Diryati memiliki beberapa indikator. Nilai ini yang nantinya masuk rapot untuk anakanak kelas empat. Dalam hal penilaian SD Karasgede berbeda dengan sekolah lainnya. Dimana di sekolah lain terdapat tes tertulis untuk menilai anak-anak. Sedangkan di SD Dorokandang hanya menilai dari hasil praktik membatik. Indikator-indikator yang dipakai oleh ibu Diryati adalah melatih anak-anak untuk bersabar, melatih anakanak agar dapat berimanjinasi, melatih anak-anak ketelitian. Beberapa indikator ini yang dinilai oleh Ibu Diryati untuk menilai praktik membatik pada anak-anak.

Pelaksanaan muatan lokal batik tulis Lasem pada kelas lima sebagian besar lebih banyak praktiknya. Materi yang diajarkan juga mengambil dari bahan buku ajar muatan lokal batik tulis Lasem. pengenalan alat dan bahan yang seharusnya dijelaskan pada kelas empat namun baru dikenalkan pada kelas lima. Materi batik tulis lasm yang diajarkan pada kelas lima yaitu sejarah batik, alat dan bahan membatik, tahapan-tahapan membatik, dan praktik memembuat pola di kain.

Mulai masuk ke kelas lima materi yang diajarkan yaitu sejarah batik tulis Lasem, perbedaan dari apa yang diajarkan pada kelas empat dan lima yaitu sejerah batik tulis Lasem pada kelas lima dijelskan lebih dalam tidak hanya sekedar anak-anak mengenal namun agar anak-anak lebih tahu tentang keberadaan batik tulis Lasem di kabupaten Rembang. pada materi ini selain dijelaskan sejarah batik juga dijelaskan keadaan batik tulis Lasem samapai dengan kondisi sekarang.

Materi yang diajarkan selanjutnya pada kelas enam yaitu praktik membatik pada kain. Pada saat praktik membatik anak-anak juga dijelaskan meteri yang lain seperti alat dan bahan yang digunakan serta tahapan-tahapan membatik. Misalnya ketika anak-anak mulai akan membatik anak-anak sebelumnya dikenalkan alat dan bahan yang dipakai untuk membatik.

Untuk kelas lima saya sudah ajarkan praktik membatik dikain. Ketika praktik saya juga sambil menjelasakan teori seperti pengetahuan tentang alat dan bahan yang dipakai untuk membatik dan tahapan-tahapan membatik. (Hasil wawancara dengan Ibu Diyarti, 51 tahun, kepala sekolah, pada tanggal 27 Maret 2011)

Praktik membatik pada kelas lima di ajarkan pada Ibu Diryati dengan sambail menjelaskan materi. Misalnya. Ketika mau menggambar pola pada kain, alat dan bahan yang dipakai adalah kain, kertas karbon, dan pensil. Sebelum memulai menggambar anak-anak dijelaskan tentang kain yang dipakai untuk membatik. Kain yang dipakai membatik ada beberapa jenis. Kain yang sering dipakai yaitu kain mori. Kain mori sendiri memiliki beberapa kualitas bahan 
sehingga terdapat beberapa harga kaon mori yang berbeda. Mendapat kain kain mori ini dapat dibeli di toko kain maupun pengusaha batik.

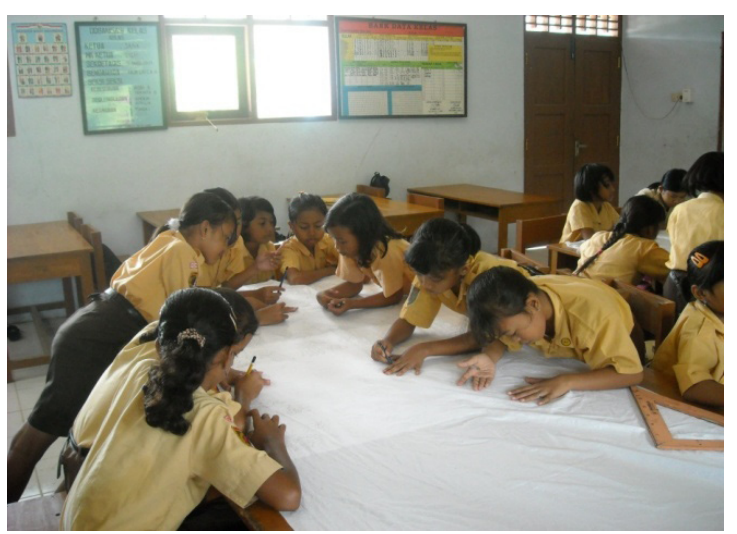

Sumber : Dokumentasi SD Karasgede,

Gambar 11. anak-anak membuat motif pada kain dengan pensil.

Gambar diatas adalah siswa SD Karasgede sedang melakukan praktik membatik pada tahapan mempola kain. terlihat beberapa anak sedang menggambar pola batik diatas kain. anak-anak tersebut dibagi beberapa kelompok, sehingga anakanak dapat merasakan praktik tersebut secara bergantian.

Tahap praktik membuat pola batik tulis Lasem pada kain telah selesai tahap selanjutnya yaitu tahap nglengkreng. Tahap nglengkreng merupakan tahap menggambar dengan cara menorehkan malam pada kain. Pada tahap ini anak-anak kelas lima diajari bagaimana cara yang benar menorehkan malam yang benar pada canting. Posisi canting yang benar akan membuat pola yang dikasih malam tidak akan terjadi yang namanya malam mblobor. Selain hal tersebut anak-anak juga diberitahu sebelum malam di dalam canting digoreskan pada kain mori sebelumnya digoreskan pada kain kecil agar dapat mengetahui malam tersebut dapat keluar atau cantingnya mengalami buntu. Langkah tersebut juga dapat mengetahui apakah malam tersebut terlalu panas sehingga ketika di torehkan pada kain akan menjadikan mlobor.

Bagi anak-anak yang belum pernak membatik tahap ini menjadi penting harus dikuasai olek anak. Tahap nglengkreng merupakan bagian yang sulit bagi anak-anak yang baru belajar. Masalah yang sering terjadi pada anak yaitu bu cantingnya buntu, bu malamnya mblobor, bu saya salah menggambar. Kalau sudah menggambar dengan malam ketika terjadi kesalahan dalam meggambar itu susah untuk mengahpusnya sehingga tahap ini memang bener-bener saya perhatikan. Saya menjelasakan bagaimana cara memegang canting yang benar. Melihat canting itu buntu atau tidak, bagaimana cara menorehkan malam dengan canting pada kain, langkah ini bener saya ajarkan pada anak-anak. (Hasil wawancara dengan Ibu Diyarti, 51 tahun, kepala sekolah, pada tanggal 27 Maret 2011)

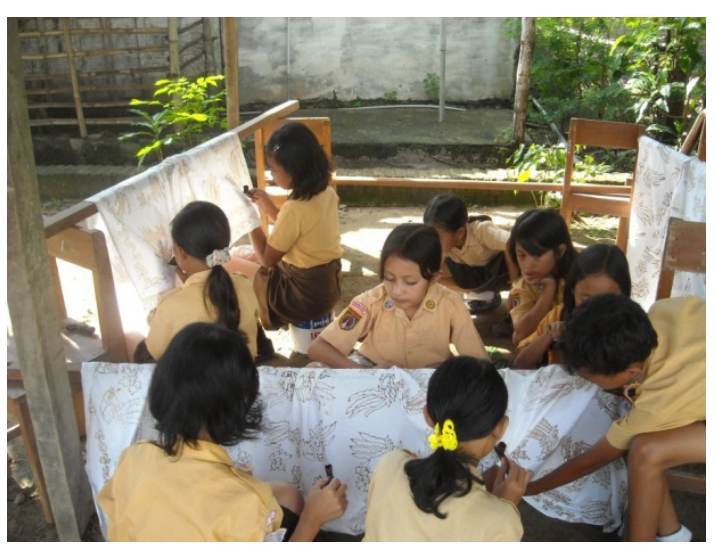

Sumber : Dokumentasi SD Karasgede

Gambar 12. anak-anak sedang nglengkreng.

Selain anak-anak juga diajrakan bagaimana cara menggunakan canting yang benar. Anak-anak kelas lima juga diajari macam-macam canting yang digunakan untuk membatik. Terdapat tiga jenis canting yang digunakan untuk membuat batik tulis Lasem, canting tersebut antara lain yaitu canting yang digunakan untuk nglengkreng, canting ini memiliki ujung yang kecil, karena digunakan untuk membuat pola batik tulis Lasem. jenis canting yang kedua yaitu canting yang digunakan untuk membuat pola yang agak besar, agar malam yang dikeluarkan 
sesuai dengan pola yang dibutuhkan. Jenis canting yang ketiga yaitu canting yang digunakan buat isen-isen, lubang canting ini besar, agar malam yang dikeluargan lebiih banyak,.

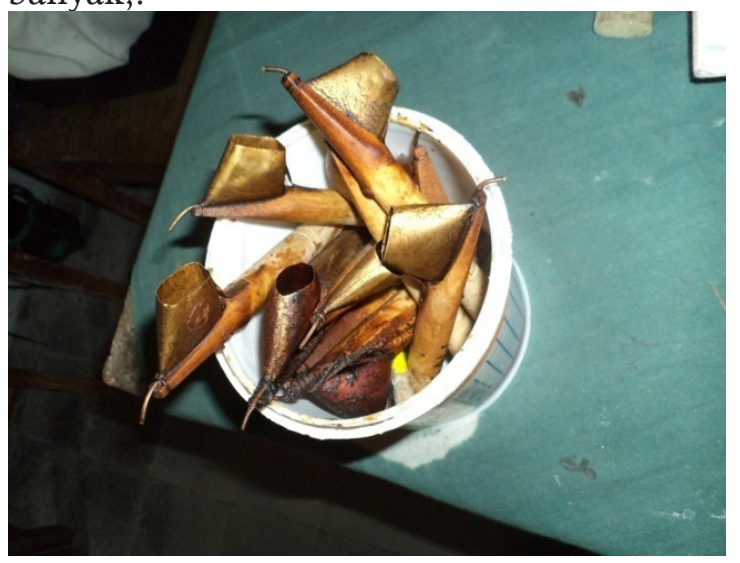

Sumber : Data primer, hasil penelitian, 2011 Gambar 13. canting alat untuk membatik.

Menurut Muslimah (2010: 24) canting adalah alat yang digunakan untuk mengalirkan malam keatas kain. canting terdiri atas tiga bagian yaitu tangkai canting, badan canting, dan cucuk. Tangkai canting terbuat dari bambu. Badan canting (nyamplungan) digunakan untuk wadah malam, badan canting terbuat darilempengan baja atau alumunium. Sedangkan bagian yang seperti paruh burung namanya cucuk sebagai tempat keluarnya cairan malam.

Berdasarkan fungsinya canting juga dapat dibedakan berdasarkan fungsinya yaitu ada canting klowong digunakan untuk membuat garis pada motif, canting cecek untuk membuat titik atau isen pada motif, cantik tembok untuk menembok kain, dan canting waleran atau seret untuk membuat dua garis yang sejajar, Muslimah (2010: 24).

Tahap berikutnya yang harus dilakukan pada anak-anak adalah tahap nerusi, nerusi ini adalah menorehkan malam pada balik kain yang telah di nglengkreng. Ibu diarty mengarahkan pada anak-anak untuk melanjutkan memola pada kain sebaliknya. Motif yang diterusi merupakan motif yang telah digambar. Sehingga pada tahap ini tidak membutuhkan waktu yang lama seperti tahap nglengkreng.

Masuk semeseter enam, anak-anak SD Karasgede masih fokus pada praktik membatik, untuk masalah materi sudah dirasa cukup bagi Ibu Diyarti. Praktik yang dilakukan pada kelas enam yaitu melanjutkan tahapan membatik selanjutnya. Namun untuk semeseter dua ditiadakan praktik membatik. Hanya ketika ujian praktik membatik dilakukan pada anak-anak kelas enam yang akan lulus. Praktik selanjutnya yaitu tahap isen-isen.

Tahap nerusi sudah selesai, tahap selanjutnya yaitu isen-isen. Tahap ini mulai diperhatikan benar-benar sama Ibu Diarty, tahap ini tidak membutuhkan waktu yang lama, karena isen-isen merupakan tahap dimana menutup pola dengan malam. Namun pada praktinya isen-isen butuh ketelitian dalam menutup pola dengan malam. Sebelum menutup pola dengan malam anak-anak harus melihat pola terlebih dahulu agar tidak terjadi kesalahan dalam menutup pola dengan malam.

Tahap isen-isen memang benar-benar saya perhatikan, kadang-kadang anakanak itu lupa sehingga salah menutup pola dengan malam. Karena serius membatik anak-anak lupa melihat pola sehingga pola yang seharusnya tidak ditutup dengan malam namun ditutup dengan malam. Agar tidak mengalami kesalahan, sedikit sedikit anak-anak saya ingatkan selalu lihat pola. (Hasil wawancara dengan Ibu Diyarti, 51 tahun, kepala sekolah, pada tanggal 27 Maret 2011)

Langkah selanjutnya dalam proses membatik yaitu tahap mewarnai dan melorot, tahap mewarnai merupakan tahap dimana kain yang telah selesai isen-isen diberi warna. Sedangkang tahap melorot adalah memberseihkan malam pada kain batik. Pada kedua tahap ini SD Karasgede tidak melakukan praktik sendiri, melainkan meminta bantuan pada pengusaha batik yang dekat dengan keberadaan sekolah SD Karasgede. Alasan dari Ibu Diarty karena biaya yang digunakan untuk tahap mewarnai sangat mahal. Untuk membeli bahan pewarna batik tulis Lasem mahal. Ketika bahan kain yang akan diwarnai 
sedikit tidak sesuai dengan biaya yang dikeluarkan. Akhirnya peroses pewarnaan diserahkan pada pengusaha batik tulis, biaya yang dikeluarkan tidak membutuhkan biaya besar. Namun agar anak-anak mengetahui langkah-langkah mewarnai Ibu Diarty menjelaskan bagamana cara untuk mewarnai dan melorot malam pada kain batik. Alat dan bahan dijelaskan pada anak-anak sambil ibu Diyarti memperagakan proses pewarnaan dan melorot pada kain batik.

Pada proses pewarnaan dan melorot pada kelas enam tetap saya jelaskan. Saya memperagakan bagaimana cara mewarnai kain batik dan bagaimana cara melorot malam pada kain batik. Alat dan bahan yang digunakan pada tahap inijuga saya jelaskan. Namun pada praktik ini ketika saya meperagakan tidak menggunakan bahan pewarna. Hanya sekedar memepragakan dan saya jelaskan pada anak-anak lagkahj-langkah untuk mewarnai kaian batik dan melorot malam pada kain batik. (Hasil wawancara dengan Ibu Diyarti, 51 tahun, kepala sekolah, pada tanggal 27 Maret 2011)

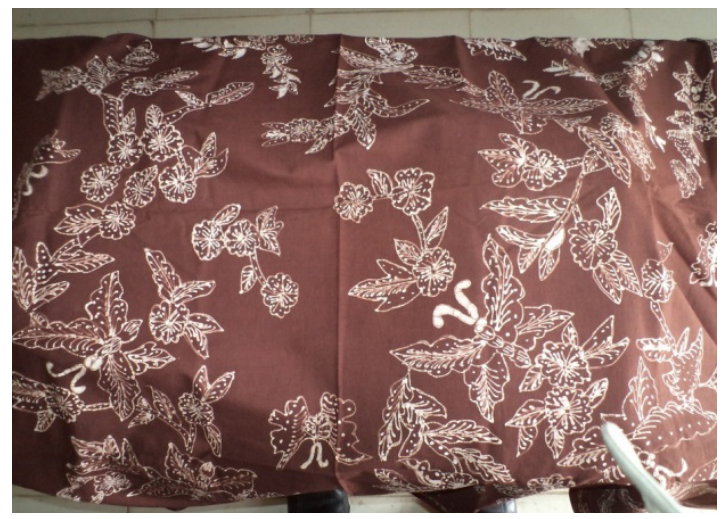

Sumber : Data primer, hasil penelitian, 2011 Gambar 14. hasil karya siswa SD karasgede

\section{5) SD Selopuro 2}

Pelaksanaan muatan lokal batik tulis Lasem di SD selopuro 2 dilaksanakan di kelas empat, lima, dan enam. Muatan lokal batk di SD Selopuro 2 dimuali pada tahun ajaran 2009/2010. Sebelumnya terdapat salah seorang guru yang dikirim untuk mengikuti pelatihan membatik yang diadakan oleh Dinas Pendidikan kabupaten Rembang yang bekerjasama dengan IPI yaitu Ibu Sri Nastiti. Pelaksanaan muatan lokal batik tulis Lasem di SD Selopuro 2 diajar oleh guru kelas masing-masing.

Pelaksanaan muatan lokal batik tulis Lasem pada kelas emapat lebih ditekannkan pada pengenalan tentang batik. Guru yang mengajar mata pelajaran muatan lokal batik tulis Lasem adalah Ibu Nani. Materi yang diberikan pada semester satu yaitu pengenalan tentang batik dan sejarah batik serat pengenalan alat dan bahan yang digunakan untuk membatik. Metode pengajaran yang digunakan oleh Ibu Nani yaitu dengan metode Ceramah. Agar siswa mudah untuk memahami materi tentang batik tulis Lasem maka Ibu Nani membawa sampel batik Tulis Lasem.

Pembelajaran batik tulis Lasem pada kelas emapat untuk materi awal saya hanya sekedar menejalskan penegtahuan tentang batik tulis Lasem. agar anak-anak mudah memahami saya membawa contoh batik tulis Lasem yang kemudian saya tunjukan kepada anak-anak. (Hasil wawancara dengan Ibu Nani, 51 tahun, guru, pada tanggal 9 April 2011).

Masuk ke materi tentang sejarah batik tulis Lasem saya menggunakan buku bahan ajar yang disediakan oleh Dinas Pendidikan Kabupaten Rembang. metode yang digunakan dalam pembelajaran muatan lokal batik tulis Lasem masih ceramah. Namun setelah selesai menjelaskan Ibu Nani mendektekan anak-anak kelas empat agar anak-anak memiliki catatan dan bisa dipelajari lagi dirumah.

Memasuki materi tentang alat dan bahan yang dipakai untuk membatik saya membawa alat dan bahan yang saya ingin jelaskan pada anak-anak kelas empat. Menjelaskan materi alat dan bahan yang dipakai untuk membatik saya membutuhkan beberapa kali pertemuan. Misalnya alat canting, canting dalam membatik saya 
digunakan untuk menorehkan malam pada kain mori yang telah digambari pola. Ibu Nani juga menjelaskan beberapa macam canting dan fungsi dari masing-masing canting tersebut. Disekolah SD Selopuro memiliki jenis canting yang lengkap, seringanya mengikuti perlombaan batik sehingga SD Selopuro diharuskan untuk memiliki peralatan yang lengkap dalam hal membatik.

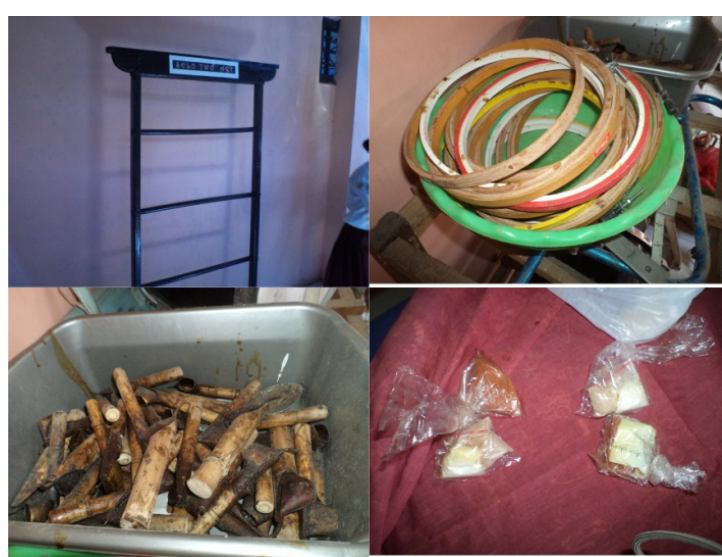

Sumber : Data primer, hasil penelitian, 2011 Gambar 15. Alat-alat dan bahan membatik tulis Lasem.

Pembelajaran materi alat dan bahan membatik pada kelas empat saya hanya membawa peralatan dan bahan yang dipakai. Dengan membawa media saya lebih mudah menjelasakn anak secara langsung, anak-anak juga bisa lebih mengerti. Ketika terdapat alat dan bahan saya juga lebih mudah menjelaskan berbagai kegunaan dari masing-masing alat dan bahan yang digunakan untuk membatik. Bahakan kadang anak-anak pada maju kedepan karena ingin melihat alat tersebut dari dekat. Sebenarnya alat dan bahan yang saya bawa ke kelas banyak ada canting, ada wajan dan kompornya, ada pemidang sebagai ganti gawangan dan lain-lain. (Hasil wawancara dengan Ibu Nani, 51 tahun, guru, pada tanggal 9 April 2011).

Memasuki semester dua pada kelas empat materi yang saya ajarkan adalah mengenalkan ragam hias batik tulis Lasem.
Berbagai macam ragam bentuk ragam hias di bawa kekelas oleh Ibu Nani agar anakanak dapat melihat ragam hias tersebut. Materi itu saya dapatkan dari guru-guru lain, motif dari pengusaha batik, dari buku ajar, dan dari internet.

Setelah mengenalkan beberapa motif batik tulis Lasem, anak-anak kelas empat mulai praktik membuat pola-pola yang telah dicontohkan. Praktik awal untuk kelas empat adalah membuat pola pada kertas gambar. Ibu Nani memberi kebebasan pada anak-anak untuk memilih motif yang mereka suka. Hasil gambar dari siswa yang mendapat nilai bagus nanti akan di pajang di dinding kelas. Tujuan dari Ibu nani adalah agar anak-anak kelas empat termotifasi untuk belajar membatik.

Pada praktik membatik pada kelas empat saya mulai pada meggambar motif batik tulis Lasem di ketas gambar. Anak-anak saya bri kebebasan dalam memilih gambar. Nanti ketika gambar anak-anak bagus akan saya pajang di dinding kelas dengan tujuan agar anak-anak yang lain termotivasi. (Hasil wawancara dengan Ibu Nani, 51 tahun, guru, pada tanggal 9 April 2011).

Anak-anak dalam menggambar motif batik tulis Lasem tidak hanya sekedar menggambar pola. Namun Ibu Nani menyuruh memberi warna pada gambar pola yang dibuat anak-anak dengan warna. Boleh pakai krayon, pensil warna, maupun cat warna. Kebebasan dalam memberi warna ini menjadi poin penilaian yang dipakai oleh Ibu Nani. Motif dan warna yang serasi dengan gambar pola batik akan mendapatkan nilai bagus.

Muatan lokal batik tulis Lasem pada kelas lima diajar sama ibu Sri Nastiti. Ibu Sri merupakan guru yang dikirim oleh kepala sekolah SD Selopuro dua untuk mengikuti pelatihan membatik di kecamatan Pancur. Materi awal yang diajarkan pada anak-anak kelas lima yaitu materi sejarah batik tulis Lasem, tahapan-tahapan membuat batik tulis Lasem, mengenalkan ragam hias batik. 


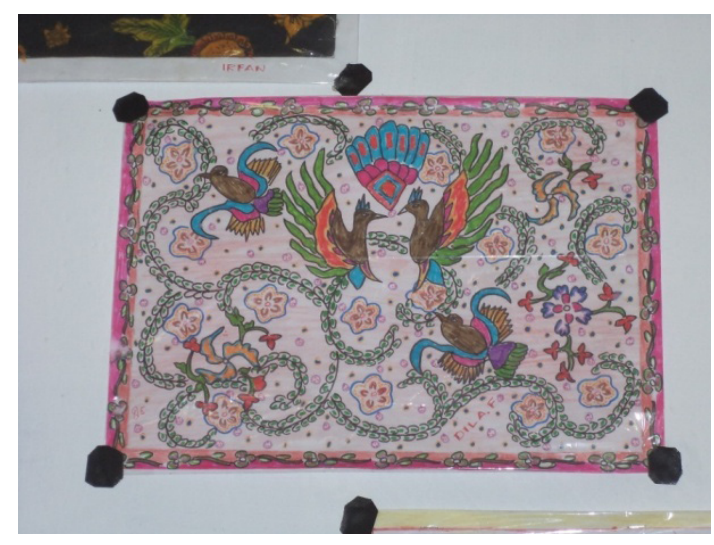

Sumber : Data primer, hasil penelitian, 2011 Gambar 16. hasil gambar siswa kelas empat SD Selopuro 2

Materi tentang sejarah batik tulis Lasem ini terdapat perbedaan dengan materi sejarah pada kelas empat. Pada tingkat kelas enam materi sejarah batik tulis Lasem lebih dibahas secara mendalam. Metode pembelajaran yang dipakai oleh Ibu Sri yaitu dengan metode ceramah. Setelah selesai menjelaskan baru mendekte pada anak-anak agar anak-anak memiliki catatan.

Materi tahapan-tahapan menbatik terdapat tujuh proses. Agar anak-anak mudah memahami selain saya jelaskan dengan meperlihatkan foto-foto tentang proses tersebut. Tahap awal saya memang hanya mengenalkan bagaimana tahapan membatik batik tulis Lasem. Natinya juga akan saya jelaskan lagi ketika pada saat praktik. Ibu Sri pada materi ini masih menggunakan metode ceramah sambil mendekte anakanak. Tahapan-tahapan membatik yaitu antara lain Ngethel, pola, nglengkreng, isenisen, nerusi, pewarnaan dan nglorot.

Saya menjelaskan materi tahapantahapan membatik menggunakan media foto untuk menjelaskan pada anak-anak. Foto-foto ini merupkan dokumentasi sekolah pada anakanak yang telah melakukan praktik membatik. Di dalam buku ajar juga sudah terdapat penjelasannya semua. Sehingga saya tidak kesulitan dalam menjelaskan pada anak-anak. Anakanak setelah saya jelaskan saya dekte agar anak-anak memiliki materi tersebut. (Hasil wawancara dengan Ibu Nani, 51 tahun, guru, pada tanggal 9 April 2011).

Setelah Ibu Sri menjelaskan pada anak-anak tentang tahapan membatik, kemudian ibu mengajak anak-anak untuk praktik membatik pada kain. parktik ini dilakukan dengan beberapa kali pertemuan. Parktik ini tujuannya yaitu membuat taplak dengan motif batik. Praktik membuat taplak ini dilakukan pada anak-anak kelas lima semester dua. Praktik ini tujuannya yaitu menjelakan tahapan-tahapan memabatik pada batik tulis Lasem agar anak-anak lebih memahami tahapan-tahapan yang harus dilakukan..

Langkah awal yaitu tahap ngethel, tahap ini yaitu mencuci kain mori yang akan digunakan untuk membatik. Kain mori akan direbus pada air mendidih selama tiga puluh menit. Setelah direbus tiga puluh menit, air tersebut kemudian di dinginkan, kain diperas dan kain diangin-anginkan dengan cara dibentang. Setelah kering kain mori ini bisa dipakai untuk membatik, tahap ini dilakukan oleh anak-anak sendiri. Karena kainya di potong-potong menjadi kecil dan dibagi beberapa kelompok maka anak-anak Di arahkan sama Ibu Sri untuk bekerjasama.

Tahapan selanjutnya yaitu membuat pola. Pada tahap ini anak-anak diberi kebebasan untuk memilih pola yang mereka suka. Disediakan oleh Ibu Sri beberapa ragam hias batik tulis Lasem untuk membuat pola. Langkah ini dipraktikan anak-anak secara bergantian, agar semua anak merasakan bagaiman cara memola pada kain. Bagi anak yang belum mahir Ibu Sri menyediakan kertas karbon untuk memblat gambar yang anak pilih. Parktik memola ini hanya membutuhkan waktu sekali pertemuan karena menggambarnya tidak dilakukan satu anak namun secara berkelompok

Pada tahap memola saya memberi kebebasan anak-anak untuk berimajinasi. Saya berikan berbagai gambar agar anak meilih gambar yang mereka suka. Tahap ini tetap 
saya arahkan agar anak-anak tidak mengalami kesalahan dalam menggambar pola. (hasil wawancara dengan Ibu Nani, 51 tahun, guru, pada tanggal 9 April 2011).

Setelah selesai memola anak-anak melanjutkan pada pertemuan berikutnya yaitu nglengkreng atau disebut juga menorehkan malam pada kain. persiapan yang dilakukan sebelum tahap ini yaitu menyiapkan kompor kecil dan wajan yaing digunakan untuk memanasi malam. Biasanya persiapan ini dilakukan pada jam istirahat sebelum mulai masuk pada jam pembelajaran. Pada saat memasuki jam pelajaran malam yang telah dipanaskan sudah siap untuk digunakan. Praktik nglengkreng ini juga dilakukan anakanak secara bergantian agar dapat merasakn semua. Arahan demi arahan diberikan oleh Ibu Sri Kepada anak-anak kelas lima agar tidak mengalami kesalahan dalam hal menorehkan malam pada pola. Pada saat pelaksanaannya terdapat anak-anak yang membatik dan ada juga anak-anak yang sedang membetulkan canting yang buntu. Langkah ini dilakukan secara bergantian pada seluruh anggota kelompok. Praktik ini tidak hanya membutuhkan praktik sekali pertemuan namun membutuhkan waktu paling tidak dua kali pertemuan.

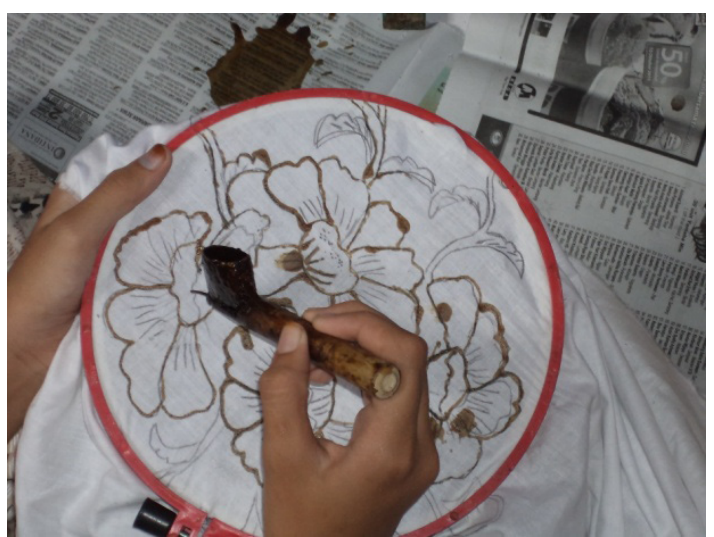

Sumber : Data primer, hasil penelitian 2011

Gambar 17. tahap nglengkreng siswa SD Selopuro 2

Tahap selanjutnya yaitu tahap isenisen, tahap ini merupakan tahap yang mudah dilakukan bagi anak-anak. Namun pelaksanaannya membutuhkan kehatihatian dalam menorehkan malam pada pola kain batik. Ibu Sri tidak henti-hentinya memberitahu anak-anak untuk selalu melihat pola sebelum menorehkan pada malam agar tidak terjadi kesalahan.

Pada tahap isen-isen anak-anak sering melakukan kesalahan mas. Mereka sering salah menutup pola dengan malam. Pola yang seharusnya tidak ditutup dengan malam namun ditutup dengan malam. Sehingga tahap ini butuh saya arahkan agar tidak terjadi keslahan pada saat menorehkan malam. (Hasil wawancara dengan Ibu Nani, 51 tahun, guru, pada tanggal 9 April 2011).

Masuk pada semester enam palaksanaan muatan lokal batik tulis Lasem pada kelas enam sudah tidak menjelaskan materi lagi. Namun meneruskan praktik yang dilakukan pada anak-anak kelas lima yang naik pada kelas enam. Praktik membatik yang dilakukan pada kelas enam yaitu tahap nerusi, tahap ini adalah membuat pola yang sama pada kain dibaliknya. Sehingga hanya mengikuti pola yang telah digambar sebelumnya. Proses ini tidak membutuhkan waktu yang lama. Pelaksanaan membatik pada kelas enam hanya sebentar akrena anakanak disiapkan untuk mengikuti kegiatan les dalam persiapan ujian nasional.

Muatan lokal batik tulis Lasem juga terdapat ujian praktik membatik yang dialakukan oleh anak-anak kelas enam. Praktik ini dilakukan dua hari yaitu hari pertama menggambar pola yang disediakan oleh guru kelas enam dan hari kedua yaitu penilaian praktik anak-anak meorehkan malam pada kain atau nglengkreng.

Pada saat hari pertama praktik ujian membatik anak-anak dibagi beberapa kelompok, kemudian setelah terbentuk kelompok anak-anak bekerjasama untuk membuat motif atau pola yang telah disediakan oleh guru. Pelaksanaan ini dilakukan di dalam kelas. Anak menggambar pola dengan memanfaatkan kertas karbon untuk memblat pola. 


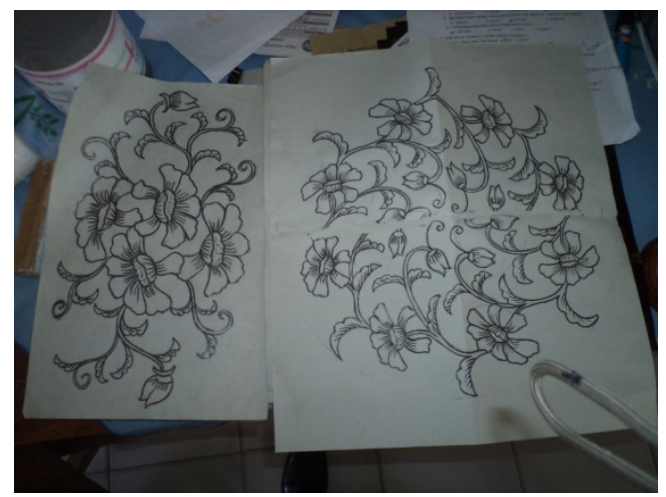

Sumber : Data primer, hasil penelitian, 2011 Gambar 18. Pola batik yang akan digambar siswa kelas enam ujian praktik membatik muatan lokal batik tulis Lasem

Pada hari kedua anak-anak mulai praktik membatik. Pelaksanaannya berada dirua membatik SD Selopuro 2. Ruangan ini berisi peralatan membatik yang lengkap. Anak-anak membatik menggunakan pemidang sebagai pengganti gawangan yang biasa dipakai oleh para pembatik. Ujian ini dilakuakn secara bergantinan sama anak-anak yang lain dalam satu kelompok. Penilaian yang dilakukan adalah secara individu sehingga satu kelompok merasakan cara membatik seluruhnya.

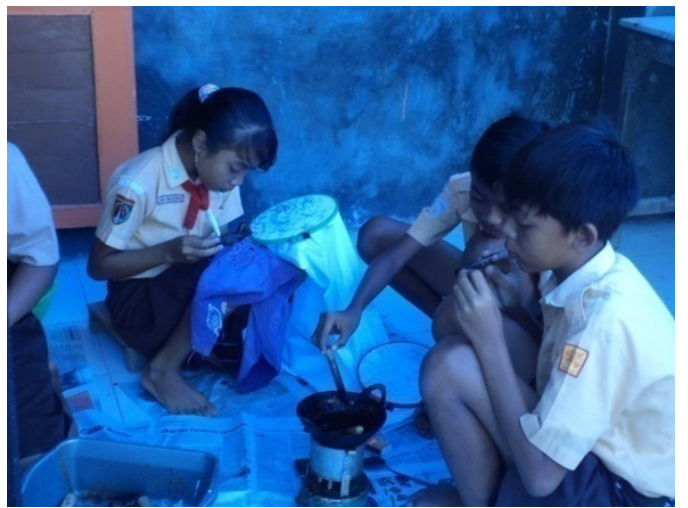

Sumber : Data primer, hasil penelitian, 2011 Gambar 19. proses ujian praktik membatik

Muatan lokal batik tulis Lasem ini juga dijadikan oleh kelima sekolah dasar untuk mengadakan ujian praktik membatik batik tulis Lasem. ujian praktik membatik yang jadi penilaian adalah pada tahap nglengkreng. Tahap ini dinilai dengan melihat kebersihan, kesesuaian gambar dengan motif batik, dan keindahan gambar batik tulis Lasem. kelima sekolah ini dalam penilaian ujian praktik membatik batik tulis Lasem tidak terdapat perbedaan.

Agar dapat melestarikan budaya batik tulis kemudian pemerintah Kabupaten Rembang mengeluarkan kebijakan untuk melestarikan budaya khas Rembang yaitu batik tulis Lasem dengan memasukkan muatan lokal batik tulis Lasem pada tingat sekolah dasar. peneliti melihat permasalahan tersebut kemudian meneliti ingin melihat peranan muatan lokal batik tulis tersebut sebagai bentuk pelestarian budaya lokal. Peneliti menggunakan teori struktural fungsional dari Talcot Parson dengan skema AGIL.

Parson mengemukakan bahwa fungsionalisme struktural dimulai dengan empat fugsi penting untuk semua sistem tindakan, terkenal dengan sistem AGIL. Parson yakin bahwa terdapat empat fungsi penting diperlukan semua sistem adaptation atau adaptasi (A), sistem ini harus mengatasi kebutuuhan situasional yang datang dari luar. Dan harus beradaptasi dengan lingkungan dan menyesuaikan lingkungan dengan kubutuhannya. Goal attaiment atau pencapaian tujuan (G), sistem harus mendefinisikan dan mencapai tujuan utamanya. Integration atau integrasi (I), sistem harus mengatur hubungan dengan bagian yang menjadi komponenya. Latensi atau pemeliharaan pola (L), sistem harus melengkapi, memelihara, dan memperbarui motivasi individu dan pola-pola budaya yang menciptakan dan mepertahankan motifasi tersebut (Ritzer dan Goodman, 2008: 257).

Adaptasi menurut Parson merupakan suatu sistem yang harus mengatasi kebutuhan situasional yang datang dari luar, dan harus beradaptasi dengan lingkungan dengan kebutuhannya. Adaptasi merupakan suatu sistem tindakan untuk mengatasi keadaan yang baru sehingga suatu sitem itu perlu beradaptasi dengan lingkungan dengan kebutuhan yang dibutuhkan. Keberadaan batik tulis Lasem yang semakin lesu dan keprihatinan pemerintah terhadap semakin berkurangnya keberadaan batik tulis Lasem menjadikan pemerintah harus beradaptasi 
agar untuk mengatasi keadaan batik tulis Lasem sebagai kebutuhan. Langakah langkah yang diambil dari pemerintah yaitu menerapkan muatan lokal batik tulis Lasem. muatan lokal batik tulis Lasem adalah usaha pemerintah untuk dapat mengatasi permasalahan kurangnya perhtian masyarakat tentang keberadaan batik tulis Lasem. Muatan lokal batik tulis Lasem merupakan sebuah tindakan yang diambil pemerintah untuk mengatasi keadaan budaya atau aset daerah yang berupa batik tulis Lasem yang mengalami kemunduran.

Menurut Departemen pendidikan Nasional (2006: 3). Muatan lokal merupakan kegiatan kurikuler untuk mengembangkan kompetensi yang disesuaikan dengan ciri khas dan potensi daerah, termasuk keunggulan daerah, yang materinya tidak dapat dikelompokkan ke dalam mata pelajaran yang ada. Substansi mata pelajaran muatan lokal ditentukan oleh satuan pendidikan, tidak terbatas pada mata pelajaran keterampilan. Jika dikaitkan dengan masalah ini maka muatan lokal batik tulis Lasem merupakan kegiatan kurikuler untuk mengembangkan komptensi yang disesuaikan dengan ciri khas dan potensi daerah. Batik tulis Lasem ini merupakan potensi daerah Rembang yang menjadi ikon untuk mengenalkan tentang Kabupaten Rembang pada umumnya dan kecamatan Lasem pada khususnya. Materi muatan lokal batik tulis lsem tidak dikelompokkan pada mata pelajaran yang lain namun menajdi mata pelajaran baru yang berdiri sendiri.

Untuk goal attaiment atau pencapaian tujuan menurut Parson, sistem harus mendefinisikan dan mencapai tujuan. Maksud Parson adalah sebuah sistem harus dapat menjelaskan tujuan yang akan dicapai sehingga apa yang mejadi tujuan dari sistem yang dibuat dapat mencapainya. Dalam hal ini muatan lokal batik tulis Lasem harus dapat mendefinisikan tujuan yang ingin di capai. Selain hal tersebut muatan lokal batik tulis Lasem ini juga harus dapat mencapai tujuan. Menurut Sudianto muatan lokal dibuat karena memiliki tujuan. Tujuan tersebut yaitu agar peserta didik memiliki wawasan, sikap dan perilaku yang mantap tentang lingkungannya serta bersedia melestarikan dan mengembangkan sumberdaya alam, sosial budaya, dan sosial ekonomi yang ada disekitarnya, sebagai aset nasional guna menunjang pembangunan daerah maupun nasional. Diterapkannya muatan lokal batik tulis Lasem diharapkan agar peserta didik dalam hal ini sekolah dasar di kecamatan Lasem memiliki wawasan, sikap dan perilaku yang mantap tentang lingkyungan maksudnya yaitu pesera didik memiliki wawasan, sikap dan perilaku yang mantap tentang budaya daerah khususnya batik tulis Lasem. serta peserta didik bersedia untuk melestarikan budaya tersebut yaitu batik tulis Lasem.

Dari tujuan diterapkannya muatan lokal ini tidak jauh beda dengan tujuan yang ingin dicapai oleh pemerintah kabupaten Rembang. Berikut adalah hasil wawancara dengan Ketua Bagian Bidang Kurikulum Dinas pendidikan kabupaten Rembang dengan Ibu Kusrini :

$\begin{array}{lrr}\text { Karena } & \text { dengan memberikan } \\ \text { pengenalan sedini mungkin itu }\end{array}$ harapan kami itu mereka akan mencintai, begitu mereka mencintai maka dia akan berusaha untuk bagaimana agar budaya kita istilahnya di uri-uri dan dilestarikan. Untuk belajar membatik itu tidak mungkin kalau tidak menggunakan hati. Harapan kami dengan sedini mungkin kita perkenalkan pada anak-anak di SD khususnya itu nanti kan batik itu tidak hanya menjadi pekerjaan alternatif namun bisa menjadi pilihan utama. (Hasil wawancara dengan ibu Kusrini, 42 tahun, Dinas Pendidikan Kabupaten Rembang pada tanggal 26 April 2011).

Dengan diterapkannya muatan lokal batik tulis Lasem pada tingkat sekolah dasar diharapkan dapat mengenalkan budaya batik tulis Lasem sedini mungkin. Perkenalan yang dimulai dari setingkat sekolah dasar paling tidak dapat mencintai dan berusaha untuk melestarikanya. Disamping hal tersebut siswa juga dapat memiliki sebuat sikap dan 
wawasan yang mantap tentang kebudayaan daerah yaitu batik tulis Lasem.

Pelaksanan muatan lokal batik tulis Lasem pada tinggkat sekolah dasar mulai pada tahun 2009. Dalam kurun waktu pelaksanaan muatan lokal batik tulis Lasem selama tiga tahun telah membawa hasil yang cukup lumayan. Hal ini terbukti terdapat beberapa anak yang senang akan pekerjaan membatik batik tulis Lasem.

Saya suka dengan batik. Ibu saya adaah pembatik namun saya tidak pernah diajari membatik, saya mendapatkan pengetahuan membatik bukan dari ibu melainkan mendapat disekolahan. Awalnya saya tidak paham karena dirumah saya hanya melihat ibu membatik, namun ketika saya diajari mebatik disekolah sekarang saya dapat membantu ibu. (Hasil wawancara dengan Riawati, 11 tahun, kelas 6 SD Selopuro 2 pada tanggal 9 April 2011)

Riawati adalah murid SD Selopuro 2 yang sekarang dapat membatik, bahkan dia sering diikutkan lomba membatik oleh sekolah untuk mewakili SD Selopuro karena memiliki bakat membatik. Riawati dalam praktik membatik sudah tidak menggunakan alat pemidang lagi seperti teman-temannya yang lain karena dia sudah terbiasa membatik.

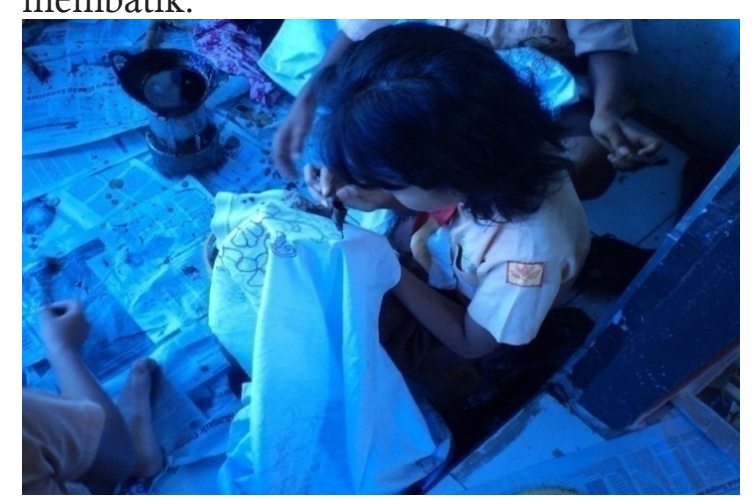

Sumber : Data primer, hasil penelitian, 2011

Gambar 20. Riawati sedang melakukan praktik membatik.

Lain lagi dengan devia, devia merupakan murid SD Karasgede. Orang tua devia adalah seorang pembatik, sehari-hari dia hanya melihat ibunya membatik. Namun dia tidak tahu menahu tentang pengetahuan batik dan bagaimana cara membatik. Ketika disekolah dia baru mendapatkan pengetahuan membatik yang diajarkan oleh Ibu Diarti.

\section{Dirumah ibu sebagai pembatik namun saya tidak pernah dibritahu tentang sejarah batik. Ketika disekolah saya baru mendapatkannya yaitu pengetahuan membatik dan sejarah tentang batik. Motif yang saya suka yaitu motif bunga ceplok. Motif ini mudah untuk digambar. (Hasil wawancara dengan Devia 11 tahun, kelas lima SD Karasgede pada tanggal 27 Maret 2011)}

Selain hal tersebut terdapat beberapa pernyataan dari beberapa guru yang mengajar muatan lokal batik tulis Lasem. masingmasing dari guru tersebut mengungkapkan bahwa mengajar muatan lokal batik tulis Lasem menambah banyak wawasan dan pengalaman yang didapat. Pada awalnya memang merasa agak kesulitan namun ketika telah berjalan manfaat yang dirasakan memang dapat mengena para guru tersebut. Pernyataan dari Ibu Sri Nastiti:

Saya memang suka batik, Mas. Sejak kecil saya suka dengan batik. Disamping hal tersebut saya lahir juga didaerah para pembatik, namun pada waktu kecil saya tidak pernah melakukan membatik, hanya melihat para pembatik memabtik kain mori. Ketika kepala sekolah menunjuk saya untuk ikut pelatihan awalnya saya ragu. Namun ketika saya jalani ternyata menyenangkan juga mengajar muatan lokal batik tulis Lasem. Sekarang manfaat dari saya mengajar muatan lokal batik tulis Lasem sedikit banyak saya bisa melakukan praktik membatik. (Hasil wawancara dengan Ibu Sri, 55 tahun, guru, pada tanggal 9 April 2011)

Pernyataan lain dari Ibu Nur dalam 
mengajar muatan lokal batik tulis Lasem yaitu sebagai berikut :

Saya memang berasal dari keluarga pembatik. Ketika kecil saya sudah diajari orang tua bagaimana cara membatik batik tulis Lasem. ketika kepala sekolah menunjuk saya mengajar muatan lokal batik tulis Lasem awalnya ragu. Karena sudah lama tidak melakukan kegiatan membatik lagi. Ketika mengajar ternyata saya tidak mengalami kendala. Mengajar muatan lokal batik tulis Lasem kepada anak-anak ternyata menyenangkan, seperti memiliki kepuasan tersendiri karena malihat anak-anak sekolah dasar bisa melakukan praktik membatik dan menghasilkan karya seni batik. (hasil wawancara dengan Ibu Nur, 26 tahun, guru, pada tanggal 10 april 2011).

Integration atau integrasi menurut Parson yaitu sistem harus mengatur hubungan dengan bagian yang menjadi komponenya. Dalam hal ini maksudnya yaitu muatan lokal batik tulis Lasem harus dapat mengatur hubungan dengan bagian komponennya. Muatan lokal batik tulis Lasem adalah sebuah alat yang dijadikan oleh pemerintah untuk melestarikan buadaya batik tulis Lasem. pelaku yang menjadi pelaksana atau komponen dari muatan lokal batik tulis Lasem adalah guru dan siswa. Sehingga guru dan siswa harus dilibatkan dalam pelaksanaan tersebut. Apalagi melihat dari sejarahnya batik tulis Lasem telah mejadi bagian dari kehidupan masyarakat.

Diterapkannya muatan lokal batik tulis Lasem pada tingkat sekolah dasar membawa perkembangan pada batik tulis Lasem. Batik tulis Lasem mulai banyak peminatnya. Hal ini diungkapkan oleh Ibu Nur ketika wawancara di Sekolah SD Jolotundo 2 yaitu sebagai berikut :

Sekarang ini batik tulis Lasem telah menjadi bagian dari kehidupan masyarakat Lasem. adanya muatan lokal batik tulis Lasem menumbuhkan rasa akan cinta dengan budaya sendiri. Pada akhirnya sekarang banyak bermunculan pengusaha batik tulis Lasem yang berasal dari masyarakat Jawa. (Hasil wawancara dengan Ibu Nur, 26 tahun, guru pada tanggal 10 April 2011)

Latensi atau pemeliharaan pola adalah sistem harus melengkapi, memelihara, dan memperbarui motivasi individu dan pola-pola budaya yang menciptakan dan mepertahankan motifasi tersebut. Suatu sistem harus dapat memelihara dan memperbarui motivasi individu dan pola-pola yang menciptakan dan dapat mempertahannkan motifasi tersebut. Agar pelaksanaan muatan lokal batik tulis Lasem tersebut masih tetap terus berjalan maka pemerintah harus dapat memperbarui motivasi individi. Individu disini yaitu siswa yang belajar muatan lokal batik tulis Lasem dan guru sebagai agen pelaksanan muatan lokal batik tulis Lasem.

Salah satu cara atau langkah yang diambil oleh pemerintah melalui Dinas Pendidikan Kabupaten Rembang yaitu dengan mengadakan perlombaan muatan lokal batik tulis Lasem. perlombaan ini menjadikan setiap sekolah untuk memunculkan siswa yang dapat membatik dan cinta akan batik tulis Lasem.

Agar muatan lokal batik tulis Lasem masih tetap berjalan kami dari Dinas Pendidikan mengadakan sebuah porlombaan membatik antar sekolah. Sehingga setiap gutu yang mengajar batik tulis Lasem berlomba-lomba untuk memcari bibit-bibit siswa yang dapat membatik. Hasil wawancara dengan Ibu Kusrini, 42 tahun, Dinas Pendidikan Kabupaten Rembang pada tanggal 26 April 2011).

Selain dari pemerintah juga terdapat sekolah yang mengadakan pameran hasil batik dari siswa-siswanya yaitu SD Karangturi. SD ini mengadakan pameran batik dengan menggundang semua guru yang terdapat di Kecamatan Lasem. Tujuannya 
yaitu untuk menggugah para pendidik atau pengajar agar dapat melihat hasil karya anakanak sekolah dasar SD Karangturi dalam hal membatik.

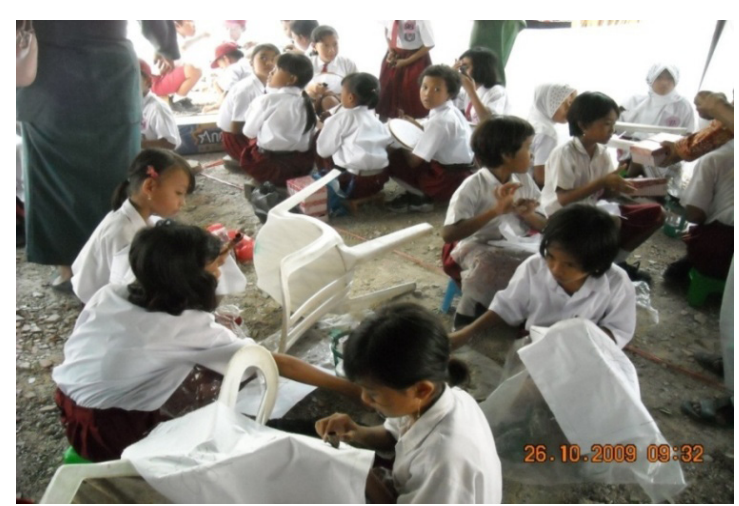

Sumber: Dokumentasi SD Karasgede

Gambar 21. pada saat lomba batik di Kabupaten Rembang.

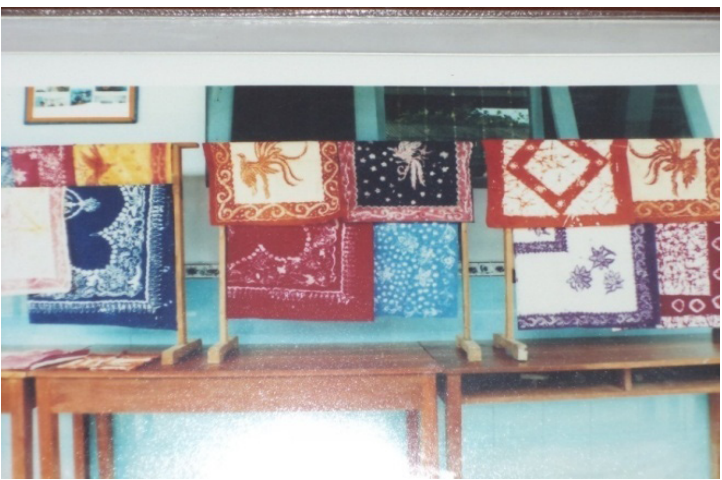

Sumber : Dokumentasi SD Karangturi

Gambar 22. Pameran batik di SD Karangturi

\section{SIMPULAN}

Berdasarkan hasil penelitian dapat disimpulkan beberapa hal sebagai berikut : Pelaksanaan muatan lokal batik tulis Lasem pada tingkat sekolah dasar di kecamatan Lasem ternyata memberikan sebuah manfaat bagi generasi muda masyarakat Lasem pada khususnya dan masyarakat rembang pada umumnya. Selain generasi muda yang merasakan manfaatnya guru yang mengajar muatan lokal batik tulis Lasem juga merasakan manfaat. Terdapatnya beberapa anak yang tertarik dengan batik tulis Lasem dan bisa membatik tulis Lasem telah sesuai dengan apa yang menjadi tujuan diterapakannya muatan lokal batik tulis di tingkat sekolah dasar, dalam hal ini wawasan yang perlu diketahui oleh anak-anak atau generasi muda tentang keberadaan budaya daerah.

Diadakan lomba batik tulis Lasem pada tingkat sekolah dasar juga memberikan motivasi kepada anak-anak untuk saling bersaing sehingga dapat memunculkan generasi-generasi muda atau pembatik cilik. Disamping hal tersebut juga menumbuhkan rasa atau sikap pada anak-anak untuk peduli dengan kebudayaan daerah kabupaten Rembang yang menjadi ciri khas yaitu batik tulis Lasem.

\section{DAFTAR PUSTAKA}

Hariyani, M. 2010. Aku Ingin Menjadi Jagoan Batik. Pengayaan Keterampilan Vokasional (kewirausahaan) untuk Anak SD. Diajukan untuk Sayembara Penulisan Buku Pengayaan 2010 Kelompok Naskah Nonfiksi. 25 Febuari.

Insriani, H. 2011. Pembelajaran Sosiologi yang Menggugah Minat Siswa. Jurnal Komunitas. 3 (1): $108-125$.

Koentjaraningrat. 1990. Pengantar Ilmu Antropologi. Jakarta: PT Rineka Cipta.

Miles dan Huberman. 1992. Analisis Data Kualitatif. Diterjemahkan oleh: Tjejep Rohandi Rohidi. Jakarta: UI Press.

Moleong, L.J. 2006. Metodologi Penelitian Kualitatif, Bandung: PT Remaja Rosdakarya.

Musanna, Al. 2010. Revitalisasi Kurikulum Muatan Lokal untuk Pendidikan Karakter melalui Evaluasi Responsif. Artikel Jurnal Pendidikan dan Kebudayaan. 16 (3): 245-255.

Prabowo, T. 2006. Pengembangan Industri Batik Di Lasem Sebagai Upaya Revitalisasi Seni Rupa Tradisional dan Peningkatan Ketahan Budaya Berbasis Pariwisata. Http://lppm.uns.ac.id/ di unduh (10/01/ 2011).

Rahayu, K. 2008. Upaya Perlindungan Batik Lasem Oleh Pemerintah Kabupaten Rembang. Tesis. Semarang: Pascasarjana Ilmu Hukum UNDIP. (pdf). Di Unduh (11/09/2010).

Ritzer, G. dan Douglas J.G. 2008. Teori Sosiologi dari Sosiologi Klasik Sampai Perkembangan Mutakhir Teori Sosial Posrmodern. Terjemahan Nurhadi. Yogyakarta: Kreasi Wacana.

Salim, A. 2007. Teori Sosiologi Klasik dan Modern. Semarang: Universitas Negeri Semarang Press.

Sudianto, M. 2006. Optimalisasi Pembelajaran Muatan Lokal dan Relevansinya dengan Kebutuhan Lapangan Kerjam pada Pendidikan Dasar 9 Tahun. Artikel Jurnal Pendidikan Dasar. 7 (2): 109-113.

Soekamto, S. 1993. Kamus Sosiologi. Jakarta : PT Raja Grafindo Persada.

Sugiarto, Dkk. 2008. Muatan Lokal Batik Tulis Lasem Kelas IV. Dinas Pendidikan Kabupaten 
Muhammad Nur Farid / Komunitas 4 (1) (2012) : 90-121

Rembang.

Sugiarto, Dkk. 2008. Muatan Lokal Batik Tulis Lasem Kelas $V$. Dinas Pendidikan Kabupaten Rembang.

Sugiarto, Dkk. 2008. Muatan Lokal Batik Tulis Lasem Kels

VI. Dinas Pendidikan Kabupaten Rembang. , 2006, Model Mata Pelajaran Muatan Lokal $S D / M I / S D L B$ - SMP/MTS/SMPLB - SMA/ $M A / S M A L B / S M K$, Jakarta: Departemen Pendidikan Nasional. http://teguhs-atu.blogspot.com/2010/02/muatanlokal.html

http://berita3rembang.wordpress.com/2011/12/09/ regenerasi-perajin-batik-tulis-Lasem/: 4/01/ 2011 jam 10.42

http://id.wikipedia.org/wiki/Sekolah_dasar: di unduh 4/01/ 2011 pukul 10.46 wib 